\title{
Binocular versus standard occlusion or blurring treatment for unilateral amblyopia in children aged three to eight years (Review)
}

\author{
Tailor V, Bossi M, Bunce C, Greenwood JA, Dahlmann-Noor A
}

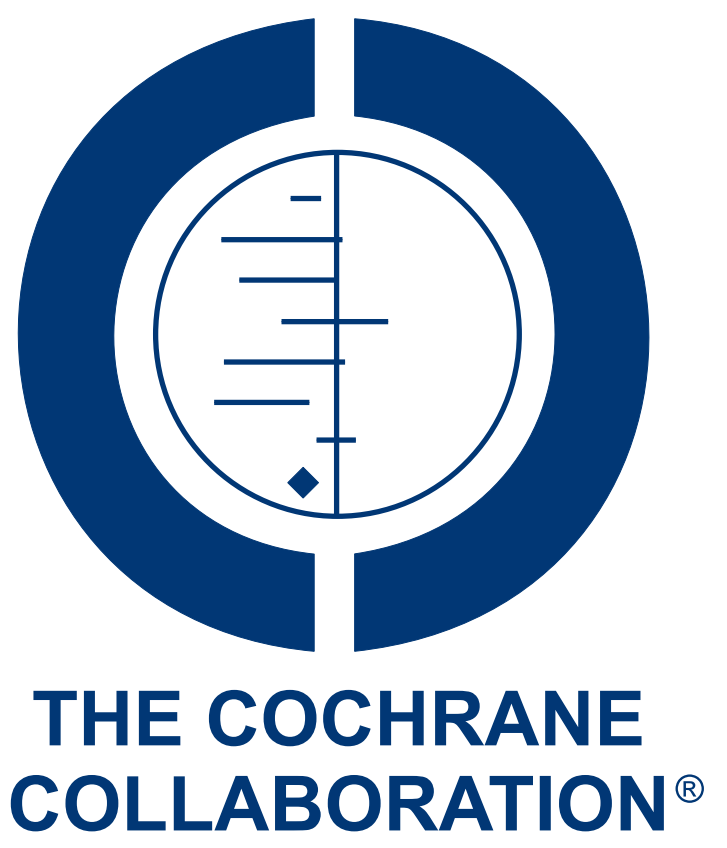

This is a reprint of a Cochrane review, prepared and maintained by The Cochrane Collaboration and published in The Cochrane Library 2015, Issue 8

http://www.thecochranelibrary.com

\section{WILEY}

Binocular versus standard occlusion or blurring treatment for unilateral amblyopia in children aged three to eight years (Review) Copyright $\odot 2015$ The Cochrane Collaboration. Published by John Wiley \& Sons, Ltd. 
TABLE OF CONTENTS

HEADER . . . . . . . . . . . . . . . . . . . . . . . . . . . . . . . . . . . . 1

ABSTRACT . . . . . . . . . . . . . . . . . . . . . . . . . . . . . . . . . . . . . . . . . . . .

PLAIN LANGUAGE SUMMARY . . . . . . . . . . . . . . . . . . . . . . . . . . . . . . . . . . .

BACKGROUND . . . . . . . . . . . . . . . . . . . . . . . . . . . . . . . . . . . . . .

OBJECTIVES . . . . . . . . . . . . . . . . . . . . . . . . . . . . . . . . . . . . . 6

METHODS . . . . . . . . . . . . . . . . . . . . . . . . . . . . . . . . . . . . . . 6

RESULTS . . . . . . . . . . . . . . . . . . . . . . . . . . . . . . . . . . . 9

Figure 1. . . . . . . . . . . . . . . . . . . . . . . . . . . . . . . . . . . . 10

DISCUSSION . . . . . . . . . . . . . . . . . . . . . . . . . . . . . . . . . . . . . 11

AUTHORS' CONCLUSIONS . . . . . . . . . . . . . . . . . . . . . . . . . . . . . . . . 11

ACKNOWLEDGEMENTS . . . . . . . . . . . . . . . . . . . . . . . . . . . . . . . . . . . . . 11

REFERENCES . . . . . . . . . . . . . . . . . . . . . . . . . . . . . . . . . . . . . . 12

CHARACTERISTICS OF STUDIES . . . . . . . . . . . . . . . . . . . . . . . . . . . . . . . . . . . . . .

DATA AND ANALYSES . . . . . . . . . . . . . . . . . . . . . . . . . . . . . . . . . . . . 20

ADDITIONAL TABLES . . . . . . . . . . . . . . . . . . . . . . . . . . . . . . . . . . . 20

APPENDICES . . . . . . . . . . . . . . . . . . . . . . . . . . . . . . . . . . . . . . 31

CONTRIBUTIONS OF AUTHORS . . . . . . . . . . . . . . . . . . . . . . . . . . . . . . . . . . . . . . . . . . . . .

DECLARATIONS OF INTEREST . . . . . . . . . . . . . . . . . . . . . . . . . . . . . . . 35

SOURCES OF SUPPORT . . . . . . . . . . . . . . . . . . . . . . . . . . . . . . . . . . . . . . . . . . . . . . . .

DIFFERENCES BETWEEN PROTOCOL AND REVIEW . . . . . . . . . . . . . . . . . . . . . . . . . . . . .

Binocular versus standard occlusion or blurring treatment for unilateral amblyopia in children aged three to eight years (Review)

Copyright $\odot 2015$ The Cochrane Collaboration. Published by John Wiley \& Sons, Ltd. 


\title{
[Intervention Review] \\ Binocular versus standard occlusion or blurring treatment for unilateral amblyopia in children aged three to eight years
}

\author{
Vijay Tailor $^{1}$, Manuela Bossi ${ }^{2}$, Catey Bunce ${ }^{3}$, John A Greenwood ${ }^{4}$, Annegret Dahlmann-Noor ${ }^{1}$ \\ ${ }^{1}$ NIHR Biomedical Research Centre at Moorfields Eye Hospital NHS Foundation Trust and UCL Institute of Ophthalmology, London, \\ UK. ${ }^{2}$ Department of Visual Neurosciences, UCL Institute of Ophthalmology, London, UK. ${ }^{3}$ Research and Development Department, \\ Moorfields Eye Hospital NHS Foundation Trust, London, UK. ${ }^{4}$ Experimental Psychology, University College London, London, UK \\ Contact address: Annegret Dahlmann-Noor, NIHR Biomedical Research Centre at Moorfields Eye Hospital NHS Foundation Trust \\ and UCL Institute of Ophthalmology, 162 City Road, London, EC1V 2PD, UK. annegret.dahlmann-noor@moorfields.nhs.uk.
}

Editorial group: Cochrane Eyes and Vision Group.

Publication status and date: New, published in Issue 8, 2015.

Review content assessed as up-to-date: 14 April 2015.

Citation: Tailor V, Bossi M, Bunce C, Greenwood JA, Dahlmann-Noor A. Binocular versus standard occlusion or blurring treatment for unilateral amblyopia in children aged three to eight years. Cochrane Database of Systematic Reviews 2015, Issue 8. Art. No.: CD011347. DOI: 10.1002/14651858.CD011347.pub2.

Copyright (C) 2015 The Cochrane Collaboration. Published by John Wiley \& Sons, Ltd.

\begin{abstract}
A B S T R A C T
Background

Current treatments for amblyopia in children, occlusion and pharmacological blurring, have had limited success, with less than twothirds of children achieving good visual acuity of at least $0.20 \log \mathrm{MAR}$ in the amblyopic eye, limited improvement of stereopsis, and poor compliance. A new treatment approach, based on the dichoptic presentation of movies or computer games (images presented separately to each eye), may yield better results, as it aims to balance the input of visual information from each eye to the brain. Compliance may also improve with these more child-friendly treatment procedures.
\end{abstract}

\section{Objectives}

To determine whether binocular treatments in children aged three to eight years with unilateral amblyopia result in better visual outcomes than conventional occlusion or pharmacological blurring treatment.

\section{Search methods}

We searched the Cochrane Eyes and Vision Group Trials Register (last date of searches: 14 April 2015), the Cochrane Central Register of Controlled Trials (CENTRAL; 2015, Issue 3), Ovid MEDLINE, Ovid MEDLINE In-Process and Other Non-Indexed Citations, Ovid MEDLINE Daily, Ovid OLDMEDLINE (January 1946 to April 2015), EMBASE (January 1980 to April 2015), the ISRCTN registry (www.isrctn.com/editAdvancedSearch), ClinicalTrials.gov (www.clinicaltrials.gov), and the World Health Organization (WHO) International Clinical Trials Registry Platform (ICTRP) (www.who.int/ictrp/search/en). We did not use any date or language restrictions in the electronic searches for trials.

\section{Selection criteria}

Two review authors independently screened the results of the search in order to identify studies that met the inclusion criteria of the review: randomised controlled trials (RCTs) that enrolled participants between the ages of three and eight years old with unilateral amblyopia, defined as best-corrected visual acuity (BCVA) worse than $0.200 \log$ MAR in the amblyopic eye, and BCVA 0.200 logMAR or better in the fellow eye, in the presence of an amblyogenic risk factor such as anisometropia, strabismus, or both. Prior to enrolment, participants were to have undergone a cycloplegic refraction and comprehensive ophthalmic examination including fundal examination.

Binocular versus standard occlusion or blurring treatment for unilateral amblyopia in children aged three to eight years (Review)

Copyright @ 2015 The Cochrane Collaboration. Published by John Wiley \& Sons, Ltd. 
In addition, participants had to have completed a period of optical treatment, if indicated, and BCVA in the amblyopic eye had to remain unchanged on two consecutive assessments despite reportedly good compliance with glasses wearing. Participants were not to have received any treatment other than optical treatment prior to enrolment. We planned to include any type of binocular viewing intervention; these could be delivered on different devices including computer monitors viewed with LCD shutter glasses or handheld screens including mobile phone screens with lenticular prism overlay. Control groups were to have received standard amblyopia treatment; this could include occlusion or pharmacological blurring of the better-seeing eye. We planned to include full-time (all waking hours) and part-time (between 1 and 12 hours a day) occlusion regimens.

\section{Data collection and analysis}

We planned to use standard methodological procedures expected by The Cochrane Collaboration. We had planned to meta-analyse the primary outcome, that is mean distance BCVA in the amblyopic eye at 12 months after the cessation of treatment.

\section{Main results}

We could identify no RCTs in this subject area.

\section{Authors' conclusions}

Further research is required to allow decisions about implementation of binocular treatments for amblyopia in clinical practice. Currently there are no clinical trials offering standardised evidence of the safety and effectiveness of binocular treatments, but results from noncontrolled cohort studies are encouraging. Future research should be conducted in the form of RCTs, using acknowledged methods of visual acuity and stereoacuity assessment with known reproducibility. Other important outcome measures include outcomes reported by users, compliance with treatment, and recurrence of amblyopia after cessation of treatment.

\section{PLAIN LANGUAGE SUMMARY}

Treatments to stimulate eye co-operation versus standard patching or blurring treatment for amblyopia (lazy eye) in children aged three to eight years

\section{Review question}

Binocular versus standard occlusion or blurring treatment for unilateral amblyopia in children aged three to eight years.

\section{Background}

At present, amblyopia ('lazy eye') in children is treated with glasses, followed by either patching or blurring of the better-seeing eye with atropine eyedrops. These treatments are not popular with children, and the amount of patching or eye drops that parents and carers can apply is often less than what was prescribed. Less than two-thirds of children develop normal vision in the lazy eye, and threedimensional vision also often does not improve. A new treatment that matches the visual information shown to the better eye to the level of vision in the lazy eye may yield better results. Children may find this approach easier to tolerate, as during treatment they play computer games or watch movies through special lenses or on modified computers.

We reviewed published reports about the success of this new treatment, compared with standard patching or eye drop blurring treatment, in children aged three to eight years with lazy eye. We searched all standard sources of information. Two review authors independently reviewed the results of this search. We planned to include only studies reporting results from randomised controlled trials (RCTs), that is those studies comparing the new treatment with a standard treatment, and where children were assigned treatment groups at random (like flipping a coin). Our main result was that we could not identify any such studies. Future updates of this review may include new studies.

We conclude that more research is needed to allow decisions about the new treatment. Whilst we did not find any RCTs, results from studies that did not include a control group are encouraging. We recommend that future research be done in the form of RCTs, and that researchers use acknowledged tests of visual acuity and three-dimensional vision to report the results. It will also be important to publish observations reported by children and families, how much the treatment was used, and if and when the vision in the lazy eye got worse after the treatment was stopped.

\section{Search date}

The evidence is current to 14 April 2015.

Binocular versus standard occlusion or blurring treatment for unilateral amblyopia in children aged three to eight years (Review) 


\section{B A C K G R O U N D}

\section{Description of the condition}

Unilateral amblyopia is a developmental defect of vision. With a prevalence of between $2 \%$ and $5 \%$, it is the most common cause of reduced vision in one eye in children in the UK (Carlton 2008; daCunha 1961; McNeil 1955; Powell 2009; Rahi 2006), and the second most common cause of functional low vision for children in low income countries (Gilbert 2008). The most common risk factors for the development of amblyopia are anisometropia (a difference in refraction or glasses prescription between the two eyes) and strabismus (misalignment of the visual axes) (Barrett 2004; McKee 2003); rarely, congenital or early childhood cataracts or other opacities of the ocular media can give rise to amblyopia by deprivation.

The imbalance of input to the brain from the two eyes results in a range of amblyopic defects in vision and gaze stability. This includes the definitive reduction in acuity or resolution and abnormal binocular function (Levi 1985; McKee 2003), with suppression of information from the amblyopic eye and poor stereopsis (three-dimensional vision) (Birch 2013; Greenwood 2012; Hess 2014; McKee 2003). This reduction in stereopsis can be associated with reduced motor skills, both in children and adults (Grant 2007; Grant 2011; Hrisos 2006; Niechwiej-Szwedo 2011; O'Connor 2010; Webber 2008a). The precise cause of amblyopia further influences the pattern of visual deficits, with anisometropic amblyopia producing additional reductions in contrast sensitivity (McKee 2003), while strabismic amblyopia yields a range of spatial disruptions including vulnerability to crowding (the disruptive influence of clutter on recognition) in the central visual field (Greenwood 2012; Levi 1985; Levi 2008; Song 2014), perceptual distortions (Barrett 2003; Mirabella 2011), and deficits in positional acuity (the ability to localise the relative position of an object in space) (Levi 1986; Neri 2006). Higher-order deficits in global-motion processing (Husk 2012; Simmers 2003) and spatial attention (the ability to direct visual attention to certain locations in the visual field) (Ho 2006; Sharma 2000) have also been reported.

If amblyopia persists into adulthood, affected individuals may be unable to take up professions that require depth perception, such as piloting aeroplanes or balancing on rooftops. Accidents affecting the better-seeing eye can lead to a severe loss of quality of life and independence (Rahi 2002). Children treated for amblyopia have lower social acceptance scores than their peers (Webber 2008b). Low self esteem and negative self image as a result of amblyopia and its treatment are common, as are feelings of depression, frustration, and embarrassment (Dixon-Woods 2006; Sinha 2008).

The distinct pattern of deficits in anisometropic and strabismic amblyopia are probably associated with specific alterations to the visual system (Birch 2000; Levi 1982; Levi 1985). Anisometropia causes blurred vision in one eye and defocused input to the visual cortex, leading to selective loss of neurons tuned to high spatial frequencies (high resolution) (Kiorpes 1998; Kiorpes 1999). In strabismus, on the other hand, the focus of retinal images is clear but misalignment of the visual axes disrupts the input to binocular cortical neurons, leading to fixation preference for one eye and subsequent visual deficits in the other eye (Birch 2013; Kiorpes 1998; Kiorpes 1999).

The cortical changes associated with amblyopia are not fully understood. Best characterised are the disruptions of neural activity in the primary visual cortex (V1) in the occipital lobe (Sengpiel 2006; Victor 1994; Vorobyov 2013; Wiesel 1963). The imbalance of visual inputs appears to induce a reallocation of V1 neurons; those receiving input from the amblyopic eye shift their responsiveness to the better-seeing eye (Kiorpes 1998; Kiorpes 1999; Li 2007; Sengpiel 2011; Vorobyov 2013; Wiesel 1963). In strabismus, although V1 neurons receive input from both eyes, the number of V1 neurons responding to stimuli from both eyes is smaller than normal, as binocular neurons in V1 only mature when receiving matching input from both eyes (Mitchell 2009). However, these disruptions to V1 function are probably insufficient to account for the extent of visual deficits in amblyopia (Kiorpes 1999). Indeed, processing in extrastriate areas is also altered (Barnes 2001; Conner 2007; Zhang 2011), which may account for the deficits in crowding (Anderson 2012), positional acuity (Maus 2010), and spatial attention (Corbetta 1995). Both ventral (object recognition) and dorsal (motion processing and action) pathways may be affected (Goodale 1992), perhaps differentially for early- versus late-onset amblyopia (Davis 2006).

The development of the functional architecture or maps of the visual cortex occurs in stages (Espinosa 2012; White 2007). The phase of maturation of the functional maps of the visual cortex is called the "'critical period'. This is because imbalance or disruption in the form of visual deprivation causes dramatic changes to the strength and organisation of the functional maps (Espinosa 2012). Different aspects of visual processing have slightly different critical periods, though they may overlap (Daw 1998; Harwerth 1986; White 2007). Thus, for area V1, the selective characteristics of these neurons are refined and matched to the input from both eyes at an earlier stage than those of extrastriate areas. Imbalance of visual input could nonetheless affect the maturation of the functional maps in a range of cortical areas.

For a long time it was held that the critical period for amblyopia treatment is identical to that of visual development, and that after the end of the critical period amblyopia cannot be induced, nor can established amblyopia be reversed (Assaf 1982; Wiesel 1963). However, newer observations have challenged the concept of a complete loss of plasticity in the visual processing areas of the brain even in adulthood, though the quality of plasticity in adulthood may differ from that in childhood (Sato 2008). Recent reports indicate that suppression can be reversed and vision successfully improved even after the end of the conventional critical period ( Evans 2011; Levi 2005; Levi 2009), though early intervention may 
still deliver better visual outcomes (Eibschitz-Tsimhoni 2000).

\section{Description of the intervention}

Amblyopia is treated by first correcting any refractive error with glasses (optical treatment, refractive adaptation). Improvement in vision is typically greatest in the first few weeks of wearing glasses but can continue for up to four months and more (Cotter 2006; Cotter 2007; Stewart 2004b; Taylor 2014; Wallace 2006). If amblyopia persists, current treatment consists of patching (occluding) the better-seeing eye for two or six hours a day, depending on the severity of the amblyopia (Awan 2005; Holmes 2003; Loudon 2006; Repka 2003; Stewart 2004a; Stewart 2004b; Stewart 2005; Taylor 2014). Successful occlusion treatment leads to an improvement of visual acuity and stereopsis (Stewart 2013; Wallace 2011). Pharmacological blurring of the better-seeing eye using atropine eye drops appears to be equivalent to occlusion treatment ( $\mathrm{Li} 2009$; PEDIG 2002; Repka 2009; Scheiman 2008).

The main drawbacks of occlusion and pharmacological blurring are poor adherence to treatment and suboptimal treatment outcomes. Lack of adherence to occlusion treatment is common. Patching the better-seeing eye functionally incapacitates the child, and children often attempt to remove the patch. Figures reported for adherence range from $41 \%$ to $57 \%$ (Awan 2005; Loudon 2006), with compliance decreasing with both an increase in severity of amblyopia and an increase in the prescribed daily dose of occlusion (Awan 2005; Loudon 2006; Moseley 1995; Stewart 2002). A questionnaire tool has been developed to measure the burden of treatment to the child and the family (Felius 2010; Holmes 2008). Whether "poor parent knowledge" of the condition contributes to poor adherence to treatment is controversial, though educational interventions may be beneficial (Dixon-Woods 2006; Loudon 2006).

Even with the best current treatment, only a fraction of children achieve near-normal visual acuity in the amblyopic eye. Using bestcorrected visual acuity (BCVA) after optical treatment as the baseline, around $25 \%$ of eyes with severe amblyopia and $58 \%$ of eyes with moderate amblyopia improve to a level of $0.2 \log$ MAR or better with occlusion treatment (Holmes 2003; Repka 2003). After treatment is discontinued, visual acuity typically regresses (Hertle 2007; Holmes 2004), and a low-dose maintenance treatment is often used to 'wean' children off treatment. Nevertheless, two years after stopping treatment, BCVA in the amblyopic eye can still be 2 lines worse than in the better-seeing eye (Repka 2005). Regression to pretreatment BCVA may occur in 30\% of cases (Malik 1975). This leaves a significant proportion of children at risk of severe functional impairment and loss of quality of life should they lose vision in the better-seeing eye at any stage during their life. In addition, stereoacuity (three-dimensional vision) improves in less than half of children (Stewart 2013).

In order to develop treatments that at the same time appeal more to children and improve not only visual acuity in the amblyopic eye but also promote binocularity, several groups have designed methods of simultaneous binocular visual stimulation.

To date, three systems have been developed, as follows.

\section{Anti-suppression therapy}

Anti-suppression therapy presents the visual scene with reduced contrast to the better-seeing eye and with normal contrast to the amblyopic eye (Hess 2010a; Hess 2010b; Hess 2011; Hess 2012; Hess 2013). This approach aims to balance V1 input to overcome interocular suppression. The difference in input to the two eyes (dichoptic presentation) can be achieved with a mirror haploscope (Hess 2010a; Hess 2010b), a head-mounted video display (Knox 2012), or lenticular prism overlays on tablet computers or screens of other hand-held devices (To 2011). The observer then has to carry out a task that requires combination of the information from the two eyes. With improving performance, the contrast of the visual scene shown to the better-seeing eye is gradually increased until contrast is equal for both eyes. A popular task is the Tetris game in which a series of falling blocks have to be fitted together to form complete lines (Black 2011). Training dose is one to two hours a day. Improvement of visual acuity and binocular vision can occur within weeks of training in adults (Hess 2010a; Hess 2012; To 2011) and children (Knox 2012).

\section{Balanced binocular viewing}

BBV uses Gaussian blur to degrade the image seen by the betterseeing eye and to balance input into the visual cortex area V1 (Bossi 2014). Children watch movies at home for an hour while wearing LCD shutter glasses. Visibility of the content across the two eyes is balanced by applying sufficient Gaussian blur to the image seen by the better-seeing eye to reduce its resolution to that of the amblyopic eye.

\section{I-BiT ${ }^{\mathrm{TM}}$}

The I-BiT ${ }^{\mathrm{TM}}$ shutter glasses system presents different parts of a two-dimensional visual scene to either eye via shutter glasses, combined with a task that requires combination of the two images (Eastgate 2006; Foss 2013; Herbison 2013; Waddingham 2006). Images are viewed with both eyes, but parts of the image can only be seen with the amblyopic eye. Presentation of the visual scene is not stereoscopic; the shutter glasses present a distinct but visually related image to both eyes (Foss 2013). The material viewed consists of videos and interactive games aimed at children aged eight years and younger.

\section{Results of non-RCT studies published to date}

The results of published cohort studies are limited by methodological factors, including the lack of a control group, the use of different testing protocols for visual acuity, stereoacuity and other psychophysical assessments, and the enrolment of participants from different age groups, different subtypes of amblyopia, and those with and without prior treatment. Nonetheless, we can still gain some insight into the likely effectiveness of these interventions. Indeed, despite these methodological limitations, a 
summary view of the published data demonstrates that binocular treatments of childhood amblyopia may be a promising new modality that merits further investigation. In Table 1 we have presented the details of these studies, including the treatment type, participant characteristics, treatment dose, and visual outcomes. These studies all involve the dichoptic presentation of images, either through head-mounted displays, hand-held devices overlaid with a lenticular layer, stereo-shutter glasses, or anaglyph glasses. The approaches diverge in terms of the content viewed during treatment, the method of binocular image adjustment, treatment durations, etc. The largest number of publications to date derive from studies using anti-suppression training, initially in adults and more recently in children (Hess 2010a; Hess 2010b; Hess 2012; Knox 2012; Li 2014; To 2011). All these studies used active gameplaying via a Tetris game during treatment. The next-most reported technique is the I-BiT approach, which uses either computer games or DVD viewing during treatment (Eastgate 2006; Cleary 2009; Foss 2013; Herbison 2013; Waddingham 2006). Finally, the balanced binocular viewing method involves movie watching with a simple game interspersed to monitor the level of interocular suppression and the difference in perception of blur (Bossi 2014).

Table 1 includes details of the reported improvements in visual acuity and stereoacuity. Across the anti-suppression studies, the mean improvement in amblyopic eye acuity ranged from 0.08 to 0.26 logMAR (Hess 2010a; Hess 2010b; Hess 2012; Knox 2012; Li 2014; To 2011). Improvements in acuity of 0.177 to $0.25 \operatorname{logMAR}$ have been reported with the I-BiT system (Cleary 2009; Herbison 2013; Waddingham 2006), whilst the BBV approach has produced a $0.26 \log$ MAR improvement in anisometropic participants (Bossi 2014). These values are comparable with the mean improvement from standard occlusion treatments, recently re-evaluated as equal to 0.22 (standard deviation: 0.16 ) at six months after occlusion, following either patching or atropine (Repka 2014). Regarding stereopsis, $67 \%$ of cases studied showed an improvement within 200 seconds of arc following anti-suppression therapy, with movement from unmeasurable to measurable stereo levels in $24 \%$ of cases (Black 2012; Hess 2011; Hess 2012; Knox 2012; To 2011). The BBV approach has also shown a mean gain in stereoacuity of 165 seconds of arc. This can be considered to be a real change, defined as a change of more than one octave on the Frisby test in all but one participant (Adams 2009; Bossi 2014). Stereoacuity improvements have not yet been documented with the I-Bit approach. These improvements in logMAR acuity and stereopsis have been observed over a range of treatment durations using the anti-suppression approach, though no link between treatment duration (5 to 40 hours) and the subtype of amblyopia has been found (Hess 2014). Recent studies have also begun to pair these treatments with non-invasive techniques to directly stimulate brain activity (either repetitive transcranial magnetic stimulation or transcranial direct current stimulation), which may temporarily disrupt interocular suppression and thus accelerate the effect of therapeutic training (Hess 2013; Spiegel 2013a; Spiegel 2013b). Binocular treatments may also have beneficial effects beyond the observed improvements in visual acuity and stereoacuity. In particular, the use of computer games or videos in these approaches is likely to engage children's attention and may thus improve compliance with treatment, which is notoriously difficult with occlusion treatment and pharmacological blurring (Wallace 2013). Indeed, high compliance with binocular treatments has been reported: $80.6 \%$ of prescribed period for I-BiT games, $92.3 \%$ for IBiT videos (Herbison 2013), and 93\% for BBV (Bossi 2014). The absence of control groups in the above-reported studies makes it difficult to assess whether these improvements in compliance will translate into improved visual outcomes, although compliance and acuity improvements do correlate strongly for patching treatments (Woodruff 1994). In addition, through treating the fundamental binocular imbalance of amblyopia, binocular approaches may promote a lower recurrence than with conventional treatment. So far, recurrence of amblyopia after cessation of treatment is reportedly low, for example $0.055 \log$ MAR at 10 weeks with I-BiT, Herbison 2013, and 0.02 logMAR at 14 weeks with BBV, Bossi 2014.

\section{How the intervention might work}

Binocular treatments have been developed against a background of studies on the effect of perceptual learning on amblyopia (Levi 2005). A range of studies has shown that targeted practice of a specific task, such as Vernier acuity, can improve performance on that task. Although this often does not transfer to other tasks or stimulus configurations (Levi 1986), in some cases training on one task does improve performance on others. For instance, training on tasks for contrast detection (Polat 2004), crowding (Hussain 2012), and stereopsis (Xi 2014) have all been found to produce improvements in the acuity of those with amblyopia. This pattern of transfer is somewhat complex; while training on a contrast task can transfer to acuity, acuity training does not transfer to contrast detection (Astle 2011). It is possible that by identifying and targeting the fundamental deficit in amblyopia, a range of amblyopic deficits could be improved at once.

Binocular treatments based on dichoptic stimulus presentation balance the input to V1 from right and left eye, either by reducing the contrast of the visual scene viewed with the better-seeing eye, or by blurring it to match the perception with the amblyopic eye. The I-BiT approach does not modify contrast or sharpness, but presents different parts of the visual scene to the amblyopic and to the better-seeing eye, and requires the user to combine the information provided to successfully play a computer game. In other words, these systems based on dichoptic presentation of images specifically target binocular summation. It is known that balancing visibility in both the amblyopic and better-seeing eye can allow both binocular summation and binocular interactions in tasks such as motion coherence and orientation discrimination (Baker 2007; Baker 2008; Mansouri 2008). Given that the binoc- 
ular imbalance is a fundamental component of amblyopia, it is likely that the specific targeting of this deficit will lead to improved outcomes for a range of amblyopic visual deficits.

\section{Why it is important to do this review}

Binocular treatments address the causal mechanisms underlying amblyopia and may deliver better outcomes than current standard treatments. In addition, these new treatment modalities are more child-friendly than conventional treatment. With homebased treatments becoming available, these new treatments may soon enter clinical use. A robust framework is required to facilitate the evaluation of RCT results and provide evidence on the benefits and harms of these treatments.

\section{O B J E C T I V E S}

To determine whether binocular treatments in children aged three to eight years with unilateral amblyopia result in better visual outcomes than conventional occlusion or pharmacological blurring treatment.

\section{METHODS}

\section{Criteria for considering studies for this review}

\section{Types of studies}

We planned to include RCTs only in this review.

\section{Types of participants}

We planned to include participants between the ages of three and eight years old with unilateral amblyopia, defined as BCVA worse than $0.200 \log$ MAR in the amblyopic eye and BCVA $0.200 \log$ MAR or better in the fellow eye, in the presence of an amblyogenic risk factor such as anisometropia, strabismus, or both. In practice, an interocular difference in visual acuity of $0.200 \operatorname{logMAR}$ or greater is usually required for a diagnosis of amblyopia.

Prior to enrolment, participants would have undergone a cycloplegic refraction and comprehensive ophthalmic examination including fundal examination. In addition, participants would have completed a period of optical treatment, and BCVA in the amblyopic eye would have remained unchanged on two consecutive assessments despite reportedly good compliance with glasses wearing. Participants would not have received any treatment other than optical treatment prior to enrolment.

\section{Types of interventions}

We planned to include any type of binocular viewing intervention; these could have been delivered on different devices including computer monitors viewed with LCD shutter glasses or handheld screens including mobile phone screens with lenticular prism overlay.

Control groups would have received standard amblyopia treatment; this could have included occlusion or pharmacological blurring of the better-seeing eye. We planned to include full-time (all waking hours) and part-time (between 1 and 12 hours a day) occlusion regimens.

\section{Types of outcome measures}

\section{Primary outcomes}

The primary outcome for this review is mean distance BCVA in the amblyopic eye at 12 months after the cessation of the interventions in logMAR units on an age-appropriate acuity test. These tests are typically administered at a distance of $3 \mathrm{~m}$ in young children; we also included measurements at $4 \mathrm{~m}$ or $6 \mathrm{~m}$.

\section{Secondary outcomes}

1. Main secondary outcome: mean distance BCVA in the amblyopic eye at any time point during or after cessation of treatment in logMAR units on an age-appropriate acuity test. These tests are typically administered at a distance of $3 \mathrm{~m}$ in young children; we also included measurements at $4 \mathrm{~m}$ or $6 \mathrm{~m}$.

2. Proportion of change in BCVA defined by the equation: "(BCVA of amblyopic eye at start minus BCVA of amblyopic eye at end of treatment) divided by (BCVA of amblyopic eye at start minus BCVA of fellow eye at end of treatment)" (Stewart 2003).

3. Stereopsis 12 months after cessation of treatment in seconds of arc.

4. Stereopsis at any time point during or after cessation of treatment in seconds of arc.

5. Proportion of participants achieving normal stereoacuity score of 60 seconds of arc or better 12 months after cessation of treatment.

6. Proportion of participants achieving normal stereoacuity score of 60 seconds of arc or better at any time point during or after cessation of treatment.

7. Proportion of participants with improvement in stereoacuity of 2 log levels or more (with 2 levels being the testretest variability for stereoacuity tests) at 12 months after cessation of treatment (Adams 2009; Wallace 2011).

8. Proportion of participants with improvement in stereoacuity of $2 \mathrm{log}$ levels or more at any time point during or after cessation of treatment.

9. Mean change in stereoacuity in log seconds of arc defined as: stereoacuity at start minus stereoacuity at end of treatment 
10. Compliance or adherence to interventions as daily dose in hours/day, determined by occlusion dose monitors, electronic compliance measures of binocular treatments, or parental treatment diaries (ratio of received dose/prescribed daily dose). 11. Compliance or adherence to interventions as total dose, determined by occlusion dose monitors, electronic compliance measures of binocular treatments, or parental treatment diaries (ratio of received dose/prescribed total dose).

12. Impact of treatment on quality of life measured by a validated tool such as Child Amblyopia Treatment Questionnaire, Carlton 2013, or Amblyopia Treatment Index, Felius 2010.

13. Proportion of participants experiencing adverse events such as diplopia (double vision) or loss of BCVA greater than 1 line in either eye.

14. Proportion of participants experiencing regression of BCVA in the amblyopic eye to baseline level, Malik 1975, or recurrence defined as a 2 or more $\log$ MAR lines $(0.2 \log$ MAR) deterioration in amblyopic eye BCVA, Holmes 2004, 12 months after cessation of treatment.

15. Where available, we included analysis of cost-effectiveness or cost-utility of treatments.

\section{Search methods for identification of studies}

\section{Electronic searches}

We searched the Cochrane Eyes and Vision Group Trials Register (last date of searches: 14 April 2015), the Cochrane Central Register of Controlled Trials (CENTRAL; 2015, Issue 3), Ovid MEDLINE, Ovid MEDLINE In-Process and Other Non-Indexed Citations, Ovid MEDLINE Daily, Ovid OLDMEDLINE (January 1946 to April 2015), EMBASE (January 1980 to April 2015), the ISRCTN registry (www.isrctn.com/editAdvancedSearch), ClinicalTrials.gov (www.clinicaltrials.gov), and the World Health Organization (WHO) International Clinical Trials Registry Platform (ICTRP) (www.who.int/ictrp/search/en). We did not use any date or language restrictions in the electronic searches for trials.

See: Appendices for details of search strategies for CENTRAL (Appendix 1), MEDLINE (Appendix 2), EMBASE (Appendix 3), ISRCTN (Appendix 4), ClinicalTrials.gov (Appendix 5), and the ICTRP (Appendix 6).

\section{Searching other resources}

We manually searched the reference lists of the trials included in the review for additional trials. We also used the Science Citation Index to identify reports that had cited the studies included in this review. With both of these strategies, we aimed to identify any relevant reports or trials that we had not identified by the electronic searches. We did not handsearch journals or conference proceedings specifically for this review.

\section{Data collection and analysis}

Data analysis would have followed the guidelines in Chapter 9 of the Cochrane Handbook for Systematic Reviews of Interventions (Deeks 2011). We had planned to meta-analyse the primary outcome, that is mean distance BCVA in the amblyopic eye at 12 months after the cessation of treatment. LogMAR acuities are normally distributed and provided we did not detect heterogeneity, we planned to meta-analyse data using the random-effects model with the mean difference as our treatment effect measure.

\section{Selection of studies}

Two review authors (VT and ADN) independently screened the results of the search (titles and abstracts) to identify studies that loosely met the inclusion criteria of the review. Review authors were not masked with respect to study authors, institution, or journal. We divided studies into 'definitely include', 'definitely exclude', and 'possibly include'. We made final judgements on inclusion or exclusion by obtaining the full-text copy of those studies in the 'possibly include' category. We had abstracts and, where necessary, full-text articles translated into English before making a final decision regarding inclusion or exclusion. We took care to identify multiple reports of the same study and, where identified, these were to be linked together. The review authors independently examined full-text reports for compliance with inclusion criteria. We resolved any disagreements over which studies to include by discussion. No consultation with a third review author (CB) was required. We have listed studies that were excluded after obtaining the full text in Characteristics of excluded studies, giving a reason for exclusion.

\section{Data extraction and management}

Two review authors (VT and ADN) were to extract data independently using a data extraction form (Table 2) developed in conjunction with the Cochrane Eyes and Vision Group, using information from Chapter 7 of the Cochrane Handbook for Systematic Reviews of Interventions (Higgins 2011a). Where data were missing or unclear, one review author (VT) was to attempt to contact the authors of the trial for unpublished data or for clarification. We were to make initial contact via email, sending a second email if there was no response. If there was still no response after the second email, we would attempt to reach authors by phone. We intended to document if this was unsuccessful in the review. We planned to enter data into Review Manager (RevMan) (RevMan 2014); one review author (VT) was to enter the data, after which a second review author (ADN) was to check for any errors.

At a minimum, we planned to extract the following data, which we intended to present in a 'Characteristics of included studies' table.

- Methodology: study design, interventions, intervention arms, duration of treatment. 
- Participants: number in each group, age, gender, comparability at baseline.

- Outcomes: primary and secondary outcomes collected and reported; for each outcome the unit of measurement would be recorded or, if a scale was used, the upper and lower limits of the scale of measurement and whether a high or low score is good.

- Results: sample size, missing participants, summary data.

- Miscellaneous: dates (when study was conducted), funding source, declarations of interest, whether correspondence was required, miscellaneous comments by the review authors.

\section{Assessment of risk of bias in included studies}

Had we identified studies meeting the inclusion criteria, two review authors (VT and ADN) would have assessed them for risk of bias according to Chapter 8 of the Cochrane Handbook for Systematic Reviews of Interventions (Higgins 2011b). We were to consider the following parameters: generation of the random sequence, allocation concealment, masking (blinding) of examiners, completeness of outcome data, and selective reporting.

We would have graded each parameter of trial quality as low, high, or unclear risk of bias.

Examples of low risk of bias:

- randomisation using computer-generated sequences or random number table;

- central allocation;

- masking of examiners;

- no missing data or missing data are balanced in numbers across intervention groups and similar reasons given across groups;

- study protocol is available with clear primary and secondary outcomes specified.

Examples of high risk of bias:

- randomisation is determined by date of visit or name (an example of quasi-randomisation, which would make study ineligible for inclusion);

- alternate allocation used (as above);

- examiners are aware of the treatment allocation prior to assessing outcomes;

- missing data are excluded and appear to be more common in one treatment arm than the other;

- none of the study's prespecified primary outcomes are reported.

Examples of unclear risk of bias:

- insufficient information in publications to allow us to make a judgement, and attempts to contact authors for clarification are unsuccessful.

\section{Measures of treatment effect}

Our primary outcome was visual acuity in the amblyopic eye in $\log M A R$ at one year after cessation of treatment. $\log M A R$ acuities tend to be normally distributed, and we aimed to use the mean difference with $95 \%$ confidence intervals as our measure of treatment effect. However, we planned to note whether or not authors assessed symmetry of their data and also which $\log$ MAR test was used, as different charts may yield different values.

Our main secondary outcome was visual acuity in the amblyopic eye in $\log$ MAR at any time point during or after cessation of treatment. This is also typically normally distributed, and we aimed to use the mean difference with $95 \%$ confidence intervals.

We planned to collate information on other outcomes but not to meta-analyse these so as to avoid any multiplicity issues.

\section{Unit of analysis issues}

Each child would have one amblyopic eye, so there would be a single observation per child. Therefore, the unit of analysis was the child.

\section{Dealing with missing data}

We planned to carry out intention-to-treat analysis for each outcome. One review author (VT) was to retrieve any missing data by contacting the authors of the relevant papers. If we failed to obtain this, but the authors had examined reasons for loss to follow-up adequately and found that losses were similar between treatment groups, we may have used available case analysis. We planned to document whether the original studies stated that they compared the characteristics of participants with complete data to those without and whether they provided any information about possible effects of missing data.

\section{Assessment of heterogeneity}

We planned to examine studies for sources of methodological and clinical heterogeneity. We intended to then assess statistical heterogeneity by:

1. examining the characteristics of the included studies;

2. looking for poor overlap of the confidence intervals on the forest plot;

3. carrying out a $\mathrm{Chi}^{2}$ test and calculation of $\mathrm{I}^{2}$ with confidence intervals. We planned to interpret values of $\mathrm{I}^{2}$ as advised by Chapter 9 of the Cochrane Handbook for Systematic Reviews of Interventions (Deeks 2011). We did not plan to adopt strict thresholds for $\mathrm{I}^{2}$ but would typically be concerned with values of $50 \%$ or more.

\section{Assessment of reporting biases}

If we had a sufficient number of trials (10 or more), we would have conducted a funnel plot to assess evidence of publication bias, although we acknowledge that asymmetry in such a plot does not always indicate publication bias. 


\section{Data synthesis}

We planned to collate all data that are relevant to our primary and secondary outcomes.

We intended to only meta-analyse our primary outcome and main secondary outcome. We were to collate data for secondary outcomes, but to avoid any multiplicity issues, and for review clarity, we did not plan to meta-analyse these data, but to report summary statistics in tables.

We had planned to prepare a 'Summary of findings' table presenting relative and absolute risks. Two review authors were to independently grade the overall quality of the evidence for each outcome using the GRADE classification (www.gradeworkinggroup.org/). We planned to include the following outcomes in the 'Summary of findings' table:

- Primary outcome, i.e. mean distance BCVA in the amblyopic eye at 12 months after the cessation of the interventions in $\log$ MAR units on an age-appropriate acuity test.

- Proportion of change in BCVA defined by the equation: "(BCVA of amblyopic eye at start minus BCVA of amblyopic eye at end of treatment) divided by (BCVA of amblyopic eye at start minus BCVA of fellow eye at end of treatment)“ (Stewart 2003).

- Proportion of participants achieving normal stereoacuity score of 60 seconds of arc or better 12 months after cessation of treatment.

- Compliance or adherence to interventions as total dose, determined by occlusion dose monitors, electronic compliance measures of binocular treatments, or parental treatment diaries (ratio of received dose/prescribed total dose).

- Impact of treatment on quality of life measured by a validated tool such as Child Amblyopia Treatment Questionnaire or Amblyopia Treatment Index (Carlton 2013; Felius 2010).

- Proportion of participants experiencing adverse events such as diplopia (double vision) or loss of BCVA greater than 1 line in either eye.

- Proportion of participants experiencing regression of BCVA in the amblyopic eye to baseline level, Malik 1975, or recurrence defined as a 2 or more logMAR lines (0.2 logMAR) deterioration in amblyopic eye BCVA, Holmes 2004, 12 months after cessation of treatment.

We planned to use a random-effects model unless there was a very small number of studies (less than three), in which case we would have used a fixed-effect model. Had we detected substantial het- erogeneity (either methodological by review of studies or by large values of $\mathrm{I}^{2}$ ), as advised by Chapter 9 of the Cochrane Handbook for Systematic Reviews of Interventions (Deeks 2011), we intended not to conduct a meta-analysis.

\section{Subgroup analysis and investigation of heterogeneity}

As we expected visual outcomes at 12 months to be similar across studies, we did not plan to carry out subgroup analysis or investigations of heterogeneity.

\section{Sensitivity analysis}

We planned sensitivity analysis to assess how robust our review results were and to study the effects of:

- missing data: we planned to consider whether or not data were likely to be missing completely at random or whether there was a possibility that missingness was related to the treatment, which might bias our results;

- excluding studies at high risk of bias, i.e. any study that scores high in any domain;

- the funding source as an indicator of potential conflict of interest, such as studies that are commercially as opposed to charity-or research-council funded.

\section{RES U L T S}

\section{Description of studies}

\section{Results of the search}

The electronic searches yielded a total of 541 references (Figure 1). The Trials Search Co-ordinator removed 105 duplicate records, screened the remaining 436 records, and removed 357 references that were not relevant to the scope of this review. We screened the remaining 79 references and discarded 70 reports as not relevant. We reviewed nine full-text reports of eight studies for possible inclusion in the review. After this assessment, we excluded eight reports of seven studies (see Characteristics of excluded studies for details). 
Figure I. Results of searching for studies for inclusion in the review.

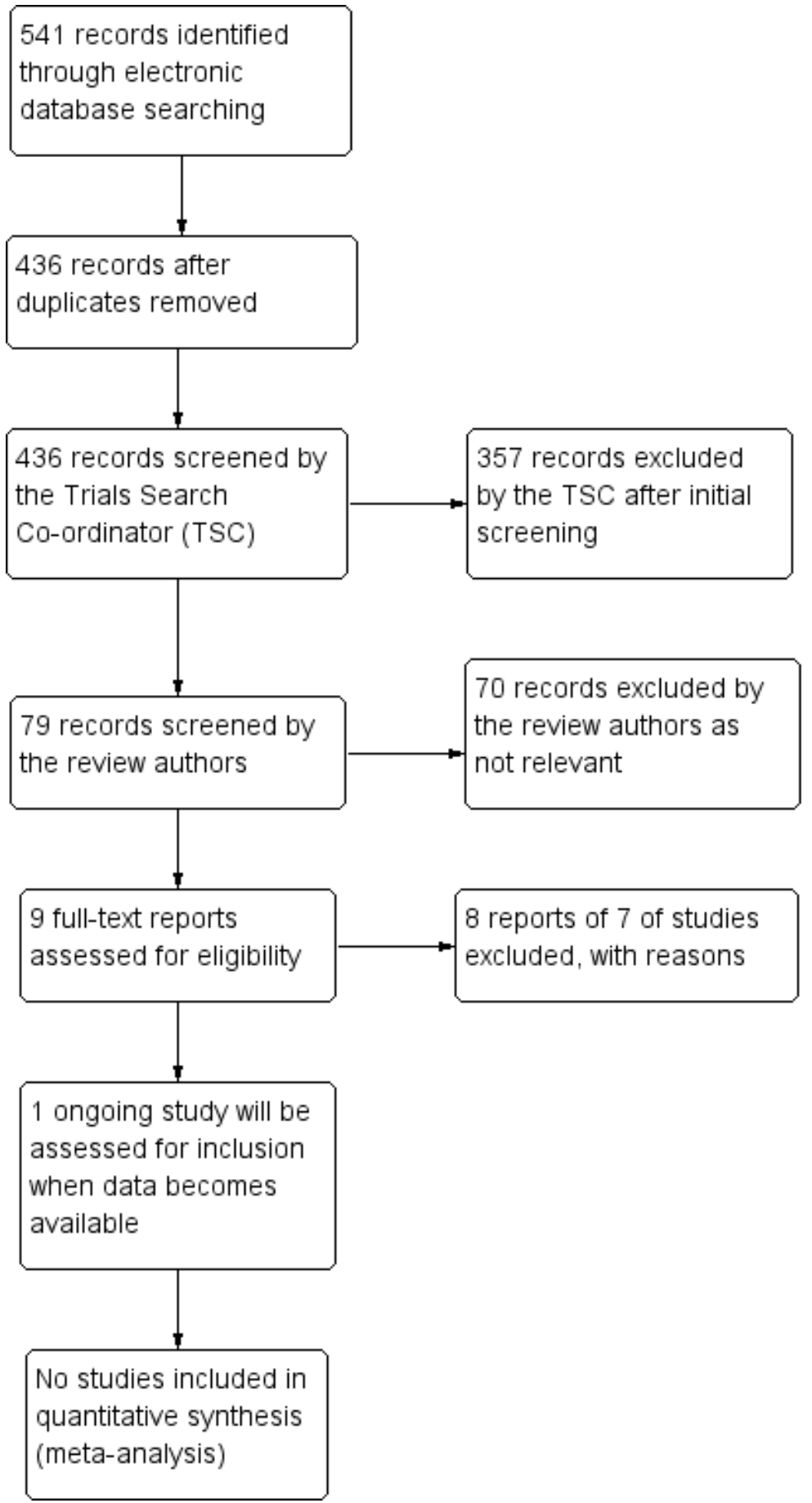


We identified one ongoing study, NCT02200211, which is currently recruiting participants and may meet the inclusion criteria once results have been published. In this RCT, children aged 5 to 17 years with amblyopia (either previously treated or untreated) will be randomised to an iPad-based binocular treatment or to conventional occlusion treatment for two hours a day. We may include a subgroup of children aged three to eight years with no previous amblyopia treatment (other than glasses) in future updates of this review. We have assigned this trial to 'ongoing studies' and will report on it in further updates of this review.

\section{Included studies}

We did not find any studies that met our inclusion criteria.

\section{Excluded studies}

We obtained eight full-text reports of seven studies for further assessment, however none of the studies met the inclusion criteria; see Characteristics of excluded studies for reasons for exclusion. An RCT of a binocular treatment, Foss 2013, has completed recruitment but not yet published findings (personal communication); however, this trial did not include a control group receiving occlusion treatment. Children with unilateral amblyopia aged four to eight years were eligible for this trial; participants were randomised to three arms: clinic-based binocular treatment using a computer game, clinic-based sham computer game, and homebased binocular treatment.

\section{Risk of bias in included studies}

We included no trials in the review.

\section{Effects of interventions}

We included no trials in the review.

\section{DISCUSSION}

\section{Summary of main results}

We did not find any RCTs that met our inclusion criteria. One ongoing RCT, ATS18 (NCT02200211), includes children aged three to eight years receiving a binocular anti-suppression treatment as first modality after optical treatment. This subgroup will be eligible for inclusion in future updates of this review. The recent I-BiT trial (NCT01702727 (Foss 2013)) does not include an occlusion treatment control arm. There is an obvious need for RCTs to evaluate the safety and efficacy of binocular treatment approaches for childhood amblyopia.

Published work in this area is so far limited to cohort studies, which we have briefly summarised below.

\section{Overall completeness and applicability of evidence}

Not applicable.

\section{A U THORS' CONCLUSIONS}

\section{Implications for practice}

There are no RCTs to guide clinical practice; further research is required to allow decisions about implementation.

\section{Implications for research}

Currently there are no clinical trials offering standardised evidence of the safety and effectiveness of binocular treatments for childhood amblyopia, but results from non-controlled cohort studies are encouraging. Future research should be conducted in the form of RCTs, using acknowledged methods of visual acuity and stereoacuity assessment with known reproducibility. Other important outcome measures include outcomes reported by users, compliance with treatment, and recurrence of amblyopia after cessation of treatment.

\section{ACKNOW LEDGEMENTS}

The Cochrane Eyes and Vision Group created and executed the electronic search strategies. We thank Jennifer Evans and Alexander Foss for their critical review of the protocol; Sue Elliott for her comments; and Anupa Shah for her assistance in the review process. 


\section{R E F E R N C E S}

\section{References to studies excluded from this review}

Astle 2011a \{published data only\}

Astle AT, McGraw PV, Webb BS. Can human amblyopia be treated in adulthood?. Strabismus 2011;19(3):99-109.

Bau 2012 \{published data only\}

Bau V, Rose K, Pollack K, Spoerl E, Pillunat LE. Effectivity of an occlusion-supporting PC-based visual training programme by horizontal drifting sinus gratings in children with amblyopia. Klinische Monatsblatter fur Augenheilkunde 2012;229(10):979-86.

Chen 2008 \{published data only\}

Chen PL, Chen JT, Fu JJ, Chien KH, Lu DW. A pilot study of anisometropic amblyopia improved in adults and children by perceptual learning: an alternative treatment to patching. Ophthalmic and Physiological Optics 2008;28(5): $422-8$.

Foss 2013 \{published data only\}

Foss AJ, Gregson RM, MacKeith D, Herbison N, Ash IM, Cobb SV, et al. Evaluation and development of a novel binocular treatment (I-BiT) system using video clips and interactive games to improve vision in children with amblyopia ('lazy eye'): study protocol for a randomised controlled trial. Trials 2013;14:145.

NCT01702727. Evaluation and development of a novel binocular treatment (I-BiTTM) system using video clips and interactive games to improve vision in children with amblyopia ('lazy eye'). clinicaltrials.gov/ct2/show/ NCT01702727 (accessed 20 November 2014).

Ide 2013 \{published data only\}

Ide T, Ishikawa M, Tsubota K, Miyao M. The effect of 3D visual simulator on children's visual acuity - a pilot study comparing two different modalities. Open Ophthalmology Journal 2013;7:69-48.

Kampf 2001 \{published data only\}

Kampf U, Muchamedjarow F, Seiler T. Supportive amblyopia treatment by means of computer games with background stimulation; a placebo controlled pilot study of 10 days. Klinische Monatsblatter fur Augenheilkunde 2001; 218(4):243-50.

Lennerstrand 1983 \{published data only\}

Lennerstrand G, Samuelsson B. Amblyopia in 4-yearold children treated with grating stimulation and fulltime occlusion; a comparative study. British Journal of Ophthalmology 1983;67(3):181-90.

\section{References to ongoing studies}

\section{NCT02200211 \{published data only\}}

NCT02200211. Study of binocular computer activities for treatment of amblyopia. clinicaltrials.gov/ct2/show/ NCT02200211 (accessed 10 October 2014).

\section{Additional references}

Adams 2009

Adams WE, Leske DA, Hatt SR, Holmes JM. Defining real change in measures of stereoacuity. Ophthalmology 2009; 116(2):281-5.

\section{Anderson 2012}

Anderson EJ, Dakin SC, Schwarzkopf DS, Rees G, Greenwood JA. The neural correlates of crowding-induced changes in appearance. Current Biology 2012;22(13): 1199-206.

\section{Assaf 1982}

Assaf AA. The sensitive period: transfer of fixation after occlusion for strabismic amblyopia. British Journal of Ophthalmology 1982;66(1):64-70.

\section{Astle 2011}

Astle AT, Webb BS, McGraw PV. The pattern of learned visual improvements in adult amblyopia. Investigative Ophthalmology and Visual Science 2011;52(10):7195-204.

Awan 2005

Awan M, Proudlock FA, Gottlob I. A randomized controlled trial of unilateral strabismic and mixed amblyopia using occlusion dose monitors to record compliance. Investigative Ophthalmology and Visual Science 2005;46(4):1435-9.

\section{Baker 2007}

Baker DH, Meese TS, Mansouri B, Hess RF. Binocular summation of contrast remains intact in strabismic amblyopia. Investigative Ophthalmology and Visual Science 2007;48(11):5332-8.

\section{Baker 2008}

Baker DH, Meese TS, Hess RF. Contrast masking in strabismic amblyopia: attenuation, noise, interocular suppression and binocular summation. Vision Research 2008;48(15):1625-40.

\section{Barnes 2001}

Barnes GR, Hess RF, Dumoulin SO, Achtman RL, Pike GB. The cortical deficit in humans with strabismic amblyopia. Journal of Physiology 2001;533(Pt 1):281-97.

\section{Barrett 2003}

Barrett BT, Pacey IE, Bradley A, Thibos LN, Morrill P. Nonveridical visual perception in human amblyopia. Investigative Ophthalmology and Visual Science 2003;44(4): 1555-67.

\section{Barrett 2004}

Barrett BT, Bradley A, McGraw PV. Understanding the neural basis of amblyopia. Neuroscientist 2004;10(2): 106-17.

Birch 2000

Birch EE, Swanson WH. Hyperacuity deficits in anisometropic and strabismic amblyopes with known ages of onset. Vision Research 2000;40(9):1035-40.

Birch 2013

Birch EE. Amblyopia and binocular vision. Progress in Retinal and Eye Research 2013;33:67-84. 


\section{Black 2011}

Black JM, Thompson B, Maehara G, Hess RF. A compact clinical instrument for quantifying suppression. Optometry and Vision Science 2011;88(2):E334-43.

\section{Black 2012}

Black JM, Hess RF, Cooperstock JR, To L, Thompson $\mathrm{B}$. The measurement and treatment of suppression in amblyopia. Journal of Visualized Experiments 2012;70: e3927.

Bossi 2014

Bossi M, Anderson EJ, Tailor V, Bex P, Greenwood JA, Dahlmann-Noor AH, et al. An exploratory study of a novel home-based binocular therapy for childhood amblyopia. Investigative Ophthalmology and Visual Science 2014;55: ARVO E-Abstract 5981.

\section{Carlton 2008}

Carlton J, Karnon J, Czoski-Murray C, Smith KJ, Marr J. The clinical effectiveness and cost-effectiveness of screening programmes for amblyopia and strabismus in children up to the age of 4-5 years: a systematic review and economic evaluation. Health Technology Assessment 2008;12(25):iii, xi-194.

\section{Carlton 2013}

Carlton, J. Identifying potential themes for the Child Amblyopia Treatment Questionnaire. Optometry and Vision Science 2013;90(8):867-73.

\section{Cleary 2009}

Cleary M, Moody AD, Buchanan A, Stewart H, Dutton GN. Assessment of a computer-based treatment for older amblyopes: the Glasgow Pilot Study. Eye 2009;23(1): $124-31$.

\section{Conner 2007}

Conner IP, Odom JV, Schwartz TL, Mendola JD. Monocular activation of V1 and V2 in amblyopic adults measured with functional magnetic resonance imaging. Journal of AAPOS 2007;11(4):341-50.

\section{Corbetta 1995}

Corbetta M, Shulman GL, Miezin FM, Petersen SE. Superior parietal cortex activation during spatial attention shifts and visual feature conjunction. Science 1995;270 (5237):802-5

\section{Cotter 2006}

Cotter SA, Edwards AR, Wallace DK, Beck RW, Arnold RW, Astle WF, et al. Treatment of anisometropic amblyopia in children with refractive correction. Ophthalmology 2006; 113(6):895-903.

\section{Cotter 2007}

Cotter SA, Edwards AR, Arnold RW, Astle WF, Barnhardt $\mathrm{CN}$, Beck RW, et al. Treatment of strabismic amblyopia with refractive correction. American Journal of Ophthalmology 2007;143(6):1060-3.

\section{daCunha 1961}

daCunha D, Jenkins EM. Amblyopia in three year olds. Medical Officer Journal 1961;106:146-8.

\section{Davis 2006}

Davis AR, Sloper JJ, Neveu MM, Hogg CR, Morgan MJ, Holder GE. Differential changes of magnocellular and parvocellular visual function in early- and late-onset strabismic amblyopia. Investigative Ophthalmology and Visual Science 2006;47(11):4836-41.

Daw 1998

Daw NW. Critical periods and amblyopia. Archives of Ophthalmology 1998;116(4):502-5.

\section{Deeks 2011}

Deeks JJ, Higgins JPT, Altman DG (editors). Chapter 9: Analysing data and undertaking meta-analyses. In: Higgins JPT, Green S (editors). Cochrane Handbook for Systematic Reviews of Interventions Version 5.1.0 (updated March 2011). The Cochrane Collaboration, 2011. Available from www.cochrane-handbook.org.

\section{Dixon-Woods 2006}

Dixon-Woods M, Awan M, Gottlob I. A qualitative study. Archives of Disease in Childhood 2006;91(6):491-4.

\section{Eastgate 2006} Eastgate RM, Griffiths GD, Waddingham PE, Moody AD, Butler TK, Cobb SV, et al. Modified virtual reality technology for treatment of amblyopia. Eye 2006;20(3): $370-4$.

Eibschitz-Tsimhoni 2000

Eibschitz-Tsimhoni M, Friedman T, Naor J, Eibschitz N, Friedman Z. Early screening for amblyogenic risk factors lowers the prevalence and severity of amblyopia. Journal of AAPOS 2000;4(4):194-9.

\section{Espinosa 2012}

Espinosa JS, Stryker MP. Development and plasticity of the primary visual cortex. Neuron 2012;75(2):230-49.

\section{Evans 2011}

Evans BJ, Yu CS, Massa E, Mathews JE. Randomised controlled trial of intermittent photic stimulation for treating amblyopia in older children and adults. Ophthalmic and Physiological Optics 2011;31(1):56-68.

\section{Felius 2010}

Felius J, Chandler DL, Holmes JM, Chu RH, Cole SR, Hill $\mathrm{M}$, et al. Evaluating the burden of amblyopia treatment from the parent and child's perspective. Journal of AAPOS 2010;14(5):389-95.

\section{Gilbert 2008}

Gilbert CE, Ellwein LB. Prevalence and causes of functional low vision in school-age children: results from standardized population surveys in Asia, Africa, and Latin America. Investigative Ophthalmology and Visual Science 2008;49(3): 877-81.

\section{Glanville 2006}

Glanville JM, Lefebvre C, Miles JN, Camosso-Stefinovic J. How to identify randomized controlled trials in MEDLINE: ten years on. Journal of the Medical Library Association 2006; 94(2):130-6. 


\section{Goodale 1992}

Goodale MA, Milner AD. Separate visual pathways for perception and action. Trends in Neurosciences 1992;15(1) $20-5$.

\section{Grant 2007}

Grant S, Melmoth DR, Morgan MJ, Finlay AL. Prehension deficits in amblyopia. Investigative Ophthalmology and Visual Science 2007;48(3):1139-48.

\section{Grant 2011}

Grant S, Moseley MJ. Amblyopia and real-world visuomotor tasks. Strabismus 2011;19(3):119-28.

\section{Greenwood 2012}

Greenwood JA, Tailor VK, Sloper JJ, Simmers AJ, Bex PJ, Dakin SC. Visual acuity, crowding, and stereo-vision are linked in children with and without amblyopia. Investigative Ophthalmology and Visual Science 2012;53(12):7655-65.

\section{Harwerth 1986}

Harwerth RS, Smith EL 3rd, Duncan GC, Crawford ML, von Noorden GK. Multiple sensitive periods in the development of the primate visual system. Science 1986; 232(4747):235-8.

\section{Herbison 2013}

Herbison N, Cobb S, Gregson R, Ash I, Eastgate R, Purdy J, et al. Interactive binocular treatment (I-BiT) for amblyopia: results of a pilot study of 3D shutter glasses system. Eye 2013;27(9):1077-83.

\section{Hertle 2007}

Hertle RW, Scheiman MM, Beck RW, Chandler DL, Bacal DA, Birch E, et al. Stability of visual acuity improvement following discontinuation of amblyopia treatment in children aged 7 to 12 years. Archives of Ophthalmology 2007;125(5):655-9.

\section{Hess 2010a}

Hess RF, Mansouri B, Thompson B. A new binocular approach to the treatment of amblyopia in adults well beyond the critical period of visual development. Restorative Neurology and Neuroscience 2010;28(6):793-802.

\section{Hess 2010b}

Hess RF, Mansouri B, Thompson B. A binocular approach to treating amblyopia: antisuppression therapy. Optometry and Vision Science 2010;87(9):697-704.

\section{Hess 2011}

Hess RF, Mansouri B, Thompson B. Restoration of binocular vision in amblyopia. Strabismus 2011;19(3): $110-8$.

Hess 2012

Hess RF, Thompson B, Black JM, Machara G, Zhang P, Bobier WR, et al. An iPod treatment of amblyopia: an updated binocular approach. Optometry 2012;83(2):87-94.

Hess 2013

Hess RF, Thompson B. New insights into amblyopia: binocular therapy and noninvasive brain stimulation. Journal of AAPOS 2013;17(1):89-93.

\section{Hess 2014}

Hess RF, Thompson B, Baker DH. Binocular vision in amblyopia: structure, suppression and plasticity. Ophthalmic and Physiological Optics 2014;34(2):146-62.

\section{Higgins 2011a}

Higgins JPT, Deeks JJ (editors). Chapter 7: Selecting studies and collecting data. In: Higgins JPT, Green S (editors), Cochrane Handbook for Systematic Reviews of Interventions Version 5.1.0 (updated March 2011). The Cochrane Collaboration, 2011. Available from www.cochrane-handbook.org.

\section{Higgins 2011b}

Higgins JPT, Altman DG, Sterne JAC (editors). Chapter 8: Assessing risk of bias in included studies. In: Higgins JPT, Green S (editors). Cochrane Handbook for Systematic Reviews of Interventions Version 5.1.0 (updated March 2011). The Cochrane Collaboration, 2011. Available from www.cochrane-handbook.org.

\section{Ho 2006}

Ho CS, Paul PS, Asirvatham A, Cavanagh P, Cline R, Giaschi DE. Abnormal spatial selection and tracking in children with amblyopia. Vision Research 2006;46(19): 3274-83.

\section{Holmes 2003}

Holmes JM, Kraker RT, Beck RW, Birch EE, Cotter SA, Everett DF, et al. A randomized trial of prescribed patching regimens for treatment of severe amblyopia in children. Ophthalmology 2003;110(11):2075-87.

\section{Holmes 2004}

Holmes JM, Beck RW, Kraker RT, Astle WF, Birch EE, Cole SR, et al. Risk of amblyopia recurrence after cessation of treatment. Journal of AAPOS 2004;8(5):420-8.

Holmes 2008

Holmes J, Strauber S, Quinn G, Cole S, Felius J, Kulp $\mathrm{M}$, et al. Further validation of the Amblyopia Treatment Index parental questionnaire. Journal of AAPOS 2008;12 (6):581-4.

\section{Hrisos 2006}

Hrisos S, Clarke MP, Kelly T, Henderson J, Wright CM. Unilateral visual impairment and neurodevelopmental performance in preschool children. British Journal of Ophthalmology 2006;90(7):836-8.

\section{Husk 2012}

Husk JS, Farivar R, Hess RF. Amblyopic deficits in processing structure-from-motion. Journal of Vision 2012; 12(4):1-12.

\section{Hussain 2012}

Hussain Z, Webb BS, Astle AT, McGraw PV. Perceptual learning reduces crowding in amblyopia and in the normal periphery. Journal of Neuroscience 2012;32(2):474-80.

\section{Kiorpes 1998}

Kiorpes L, Kiper DC, O'Keefe LP, Cavanaugh JR, Movshon JA. Neuronal correlates of amblyopia in the visual cortex of macaque monkeys with experimental strabismus and 
anisometropia. Journal of Neuroscience 1998;18(16):

6411-24.

\section{Kiorpes 1999}

Kiorpes L, McKee SP. Neural mechanisms underlying amblyopia. Current Opinion in Neurobiology 1999;9(4): 480-6.

Knox 2012

Knox PJ, Simmers AJ, Gray LS, Cleary M. An exploratory study: prolonged periods of binocular stimulation can provide an effective treatment for childhood amblyopia. Investigative Ophthalmology and Visual Science 2012;53(2): $817-24$.

\section{Levi 1982}

Levi DM, Klein S. Differences in vernier discrimination for grating between strabismic and anisometropic amblyopes. Investigative Ophthalmology and Visual Science 1982;23(3): 398-407.

Levi 1985

Levi DM, Klein SA. Vernier acuity, crowding and amblyopia. Vision Research 1985;25(7):979-91.

Levi 1986

Levi DM, Klein SA. Sampling in spatial vision. Nature 1986;320(6060):360-2.

Levi 2005

Levi DM. Perceptual learning in adults with amblyopia: a reevaluation of critical periods in human vision. Developmental Psychobiology 2005;46(3):222-32.

Levi 2008

Levi DM. Crowding - an essential bottleneck for object recognition: a mini-review. Vision Research 2008;48(5): 635-54.

Levi 2009

Levi DM, Li RW. Improving the performance of the amblyopic visual system. Philosophical Transactions of the Royal Society of London. Series B, Biological Sciences 2009; 364(1515):399-407.

Li 2007

Li X, Dumoulin SO, Mansouri B, Hess RF. The fidelity of the cortical retinotopic map in human amblyopia. European Journal of Neuroscience 2007;25(5):1265-77.

Li 2009

Li T, Shotton K. Conventional occlusion versus pharmacologic penalization for amblyopia. Cochrane Database of Systematic Reviews 2009, Issue 4. [DOI: 10.1002/14651858.CD006460.pub2]

\section{Li 2014}

Li SL, Jost RM, Morale SE, Stager DR, Dao L, Stager D, et al. A binocular iPad treatment for amblyopic children. Eye 2014;28(10):1246-53.

\section{Loudon 2006}

Loudon SE, Fronius M, Looman CW, Awan M, Simonsz B, van der Maas PJ, et al. Predictors and a remedy for noncompliance with amblyopia therapy in children measured with the occlusion dose monitor. Investigative Ophthalmology and Visual Science 2006;47(10):4393-400.

\section{Malik 1975}

Malik SR, Virdi PS, Goel BK. Follow-up results of occlusion and pleoptic treatment. Acta Ophthalmologica 1975;53(4): 620-6.

Mansouri 2008

Mansouri B, Thompson B, Hess RF. Measurement of suprathreshold binocular interactions in amblyopia. Vision Research 2008;48(28):2775-84

Maus 2010

Maus GW, Weigelt S, Nijhawan R, Muckli L. Does area V3A predict positions of moving objects?. Frontiers in Psychology 2010;1:186.

\section{McKee 2003}

McKee SP, Levi DM, Movshon JA. The pattern of visual deficits in amblyopia. Journal of Vision 2003;3(5):380-405.

McNeil 1955

McNeil J. Patterns of visual deficits in children. British Medical Journal 1955;39:820-5.

\section{Mirabella 2011}

Mirabella G, Hay S, Wong AM. Deficits in perception of images of real-world scenes in patients with a history of amblyopia. Archives of Ophthalmology 2011;129(2): 176-83.

Mitchell 2009

Mitchell DE, Sengpiel F. Neural mechanisms of recovery following early visual deprivation. Philosophical Transactions of the Royal Society of London. Series B, Biological Sciences 2009;364(1515):383-98.

\section{Moseley 1995}

Moseley M, Fielder A. Measurement of compliances with occlusion therapy. Journal of Pediatric Ophthalmology and Strabismus 1995;32(6):399-400.

Neri 2006

Neri P, Levi DM. Spatial resolution for feature binding is impaired in peripheral and amblyopic vision. Journal of Neurophysiology 2006;96(1):142-53.

Niechwiej-Szwedo 2011

Niechwiej-Szwedo E, Goltz HC, Chandrakumar M, Hirji Z, Wong AM. Effects of anisometropic amblyopia on visuomotor behavior, III: Temporal eye-hand coordination during reaching. Investigative Ophthalmology and Visual Science 2011;52(8):5853-61.

O'Connor 2010

O'Connor AR, Birch EE, Anderson S, Draper H. The functional significance of stereopsis. Investigative Ophthalmology and Visual Science 2010;51(4):2019-23.

PEDIG 2002

Pediatric Eye Disease Investigator Group. A randomized trial of atropine vs patching for treatment of moderate amblyopia in children. Archives of Ophthalmology 2002;120 (3):268-78

\section{Polat 2004}

Polat U, Ma-Naim T, Belkin M, Sagi D. Improving vision in adult amblyopia by perceptual learning. Proceedings of the 
National Academy of Sciences of the United States of America 2004;101(17):6692-7.

\section{Powell 2009}

Powell C, Hatt SR. Vision screening for amblyopia in childhood. Cochrane Database of Systematic Reviews 2009, Issue 3. [DOI: 10.1002/14651858.CD005020.pub3]

Rahi 2002

Rahi J, Logan S, Timms C, Russell-Eggitt I, Taylor D. Risk, causes, and outcomes of visual impairment after loss of vision in the non-amblyopic eye: a population-based study. The Lancet 2002;360(9333):597-602.

Rahi 2006

Rahi JS, Cumberland PM, Peckham CS. Does amblyopia affect educational, health, and social outcomes? Findings from the 1958 British birth cohort. BMJ 2006;332(7545): $820-5$.

\section{Repka 2003}

Repka MX, Beck RW, Holmes JM, Birch EE, Chandler DL, Cotter SA, et al. A randomized trial of patching regimens for treatment of moderate amblyopia in children. Archives of Ophthalmology 2003;121(5):603-11.

\section{Repka 2005}

Repka MX, Wallace DK, Beck RW, Kraker RT, Birch EE, Cotter SA, et al. Two-year follow-up of a 6-month randomized trial of atropine vs patching for treatment of moderate amblyopia in children. Archives of Ophthalmology 2005;132(2):149-57.

\section{Repka 2009}

Repka MX, Kraker RT, Beck RW, Birch E, Cotter SA, Holmes JM, et al. Treatment of severe amblyopia with weekend atropine: results from 2 randomized clinical trials. Journal of AAPOS 2009;13(3):258-63.

Repka 2014

Repka MX, Kraker RT, Holmes JM, Summers AI, Glaser SR, Barnhardt CN, et al. Atropine vs patching for treatment of moderate amblyopia: follow-up at 15 years of age of a randomized clinical trial. JAMA Ophthalmology 2014;132 (7):799-805.

\section{RevMan 2014}

The Nordic Cochrane Centre, The Cochrane Collaboration. Review Manager (RevMan). 5.3. Copenhagen: The Nordic Cochrane Centre, The Cochrane Collaboration, 2014.

\section{Sato 2008}

Sato M, Stryker MP. Distinctive features of adult ocular dominance plasticity. Journal of Neuroscience 2008;28(41): 10278-86.

\section{Scheiman 2008}

Scheiman MM, Hertle RW, Kraker RT, Beck RW, Birch EE, Felius J, et al. Patching vs atropine to treat amblyopia in children aged 7 to 12 years: a randomized trial. Archives of Ophthalmology 2008;126(12):1634-42.

\section{Sengpiel 2006}

Sengpiel F, Jirmann KU, Vorobyov V, Eysel UT. Strabismic suppression is mediated by inhibitory interactions in the primary visual cortex. Cerebral Cortex 2006;16(12):1750-8.

\section{Sengpiel 2011}

Sengpiel F. Experimental models of amblyopia: insights for prevention and treatment. Strabismus 2011;19(3):87-90.

\section{Sharma 2000}

Sharma V, Levi DM, Klein SA. Undercounting features and missing features: evidence for a high-level deficit in strabismic amblyopia. Nature Neuroscience 2000;3(5): 496-501.

\section{Simmers 2003}

Simmers AJ, Ledgeway T, Hess RF, McGraw PV. Deficits to global motion processing in human amblyopia. Vision Research 2003;43(6):729-38.

Sinha 2008

Sinha I, Jones L, Smyth RL, Williamson PR. A systematic review of studies that aim to determine which outcomes to measure in clinical trials in children. PLoS Medicine 2008;5 (4):e96.

Song 2014

Song S, Levi DM, Pelli DG. A double dissociation of the acuity and crowding limits to letter identification, and the promise of improved visual screening. Journal of Vision 2014;14(5):3.

\section{Spiegel 2013a}

Spiegel DP, Byblow WD, Hess RF, Thompson B. Anodal transcranial direct current stimulation transiently improves contrast sensitivity and normalizes visual cortex activation in individuals with amblyopia. Neurorehabilitation and Neural Repair 2013;27(8):760-9.

\section{Spiegel 2013b}

Spiegel DP, Li J, Hess RF, Byblow WD, Deng D, Yu M, et al. Transcranial direct current stimulation enhances recovery of stereopsis in adults with amblyopia. Neurotherapeutics 2013;10(4):831-9.

\section{Stewart 2002}

Stewart CE, Fielder AR, Stephens DA, Moseley MJ. Design of the Monitored Occlusion Treatment of Amblyopia Study (MOTAS). British Journal of Ophthalmology 2002;86(8): 915-9.

Stewart 2003

Stewart CE, Moseley MJ, Fielder AR. Defining and measuring treatment outcome in unilateral amblyopia. British Journal of Ophthalmology 2003;87(10):1229-31.

\section{Stewart 2004a}

Stewart CE, Moseley MJ, Stephens DA, Fielder AR. Treatment dose-response in amblyopia therapy: the Monitored Occlusion Treatment of Amblyopia Study (MOTAS). Investigative Ophthalmology and Visual Science 2004;45(9):3048-54.

\section{Stewart 2004b}

Stewart CE, Moseley MJ, Fielder AR, Stephens DA. Refractive adaptation in amblyopia: quantification of effect and implications for practice. British Journal of Ophthalmology 2004;88(12):1552-6. 


\section{Stewart 2005}

Stewart CE, Fielder AR, Stephens DA, Moseley MJ. Treatment of unilateral amblyopia: factors influencing visual outcome. Investigative Ophthalmology and Visual Science 2005;46(9):3152-60.

\section{Stewart 2013}

Stewart CE, Wallace MP, Stephens DA, Fielder AR, Moseley MJ, MOTAS Cooperative. The effect of amblyopia treatment on stereoacuity. Journal of AAPOS 2013;17(2): $166-73$.

Taylor 2014

Taylor K, Elliott S. Interventions for strabismic amblyopia. Cochrane Database of Systematic Reviews 2014, Issue 7. [DOI: 10.1002/14651858.CD006461.pub4]

To 2011

To L, Thompson B, Blum JR, Maehara G, Hess RF, Cooperstock JR. A game platform for treatment of amblyopia. IEEE Transactions on Neural Systems and Rehabilitation Engineering 2011;19(3):280-9.

\section{Victor 1994}

Victor JD, Purpura K, Katz E, Mao B. Population encoding of spatial frequency, orientation, and color in macaque V1. Journal of Neurophysiology 1994;72(5):2151-66.

Vorobyov 2013

Vorobyov V, Kwok JC, Fawcett JW, Sengpiel F. Effects of digesting chondroitin sulfate proteoglycans on plasticity in cat primary visual cortex. Journal of Neuroscience 2013;33 (1):234-43.

Waddingham 2006

Waddingham PE, Butler TK, Cobb SV, Moody AD, Comaish IF, Haworth SM, et al. Preliminary results from the use of the novel Interactive binocular treatment (I-BiT) system, in the treatment of strabismic and anisometropic amblyopia. Eye 2006;20(3):375-8.

Wallace 2006

Wallace DK, Edwards AR, Cotter SA, Beck RW, Arnold RW, Astle WF, et al. A randomized trial to evaluate 2 hours of daily patching for strabismic and anisometropic amblyopia in children. Ophthalmology 2006;113(6):904-12.

\section{Wallace 2011}

Wallace DK, Lazar EL, Melia M, Birch EE, Holmes JM, Hopkins KB, et al. Stereoacuity in children with anisometropic amblyopia. Journal of AAPOS 2011;15(5): 455-61.

\section{Wallace 2013}

Wallace MP, Stewart CE, Moseley MJ, Stephens DA, Fielder AR. Compliance with occlusion therapy for childhood amblyopia. Investigative Ophthalmology and Visual Science 2013;54(9):6158-66.

\section{Webber 2008a}

Webber AL, Wood JM, Gole GA, Brown B. The effect of amblyopia on fine motor skills in children. Investigative Ophthalmology and Visual Science 2008;49(2):594-603.

\section{Webber 2008b}

Webber AL, Wood JM, Gole GA, Brown B. Effect of amblyopia on self-esteem in children. Optometry and Vision Science 2008;85(11):1074-81.

\section{White 2007}

White LE, Fitzpatrick D. Vision and cortical map development. Neuron 2007;56(2):327-38.

Wiesel 1963

Wiesel TN, Hubel DH. Single-cell responses in striate cortex of kittens deprived of vision in one eye. Journal of Neurophysiology 1963;26:1003-17.

\section{Woodruff 1994}

Woodruff G, Hiscox F, Thompson JR, Smith LK. Factors affecting the outcome of children treated for amblyopia. Eye 1994;8(Pt 6):627-31.

\section{Xi 2014}

Xi J, Jia WL, Feng LX, Lu ZL, Huang CB. Perceptual learning improves stereoacuity in amblyopia. Investigative Ophthalmology and Visual Science 2014;55(4):2384-91.

\section{Zhang 2011}

Zhang B, Tao X, Wensveen JM, Harwerth RS, Smith EL 3rd, Chino YM. Effects of brief daily periods of unrestricted vision during early monocular form deprivation on development of visual area 2. Investigative Ophthalmology and Visual Science 2011;52(10):7222-31.

\section{References to other published versions of this review}

\section{Tailor 2014}

Tailor V, Bossi M, Bunce C, Greenwood JA, DahlmannNoor A. Binocular versus standard occlusion or blurring treatment for unilateral amblyopia in children aged three to eight years. Cochrane Database of Systematic Reviews 2014, Issue 11. [DOI: 10.1002/14651858.CD011347]

* Indicates the major publication for the study 


\section{CHARACTERISTICS OF STUDIES}

\section{Characteristics of excluded studies [ordered by study ID]}

\begin{tabular}{|c|c|}
\hline Study & Reason for exclusion \\
\hline Astle 2011a & Perceptual learning to reduce stereo deficits. Adults; review article; no randomisation \\
\hline Bau 2012 & $\begin{array}{l}\text { Stimulation therapy: drifting sinus grating combined with computer games. Better-seeing eye occluded during } \\
\text { treatment, so treatment not binocular }\end{array}$ \\
\hline Chen 2008 & $\begin{array}{l}\text { Perceptual learning approach, grey-level gratings, Gabor patch contrast detection task. Better-seeing eye oc- } \\
\text { cluded during treatment, so treatment not binocular; no randomisation }\end{array}$ \\
\hline Foss 2013 & None of the treatment groups received an occlusion or blurring treatment \\
\hline Ide 2013 & Treatment not for amblyopia \\
\hline Kampf 2001 & $\begin{array}{l}\text { Stimulation therapy: drifting sinus grating combined with foreground game. Better-seeing eye occluded during } \\
\text { treatment, so treatment not binocular }\end{array}$ \\
\hline Lennerstrand 1983 & $\begin{array}{l}\text { Stimulation therapy: grating; full-time occlusion. Better-seeing eye occluded during treatment, so treatment } \\
\text { not binocular }\end{array}$ \\
\hline
\end{tabular}

\section{Characteristics of ongoing studies [ordered by study ID]}

\section{NCT02200211}

Trial name or title

\begin{tabular}{ll}
\hline Methods & $\begin{array}{l}\text { Parallel-group RCT } \\
\text { Masking: single blind (outcomes assessor) }\end{array}$ \\
\hline Participants & Children aged 5-17 \\
\hline Interventions & $\begin{array}{l}\text { iPad® device } \\
\text { Patching } 2 \text { hours per day, } 7 \text { days per week }\end{array}$ \\
\hline Outcomes & $\begin{array}{l}\text { Following text taken from clinicaltrials.gov } \\
\text { Primary Outcome Measures: } \\
\text { Distance Visual Acuity [Time Frame: } 16 \text { weeks] [Designated as safety issue: No] Monocular distance visual } \\
\text { acuity in current refractive correction (if required) in each eye by a certified examiner using the electronic } \\
\text { ATS-HOTV visual acuity protocol for children }<7 \text { years and the E-ETDRS visual acuity protocol for children } \\
\geq 7 \text { years on a study-certified acuity tester displaying single surrounded optotypes } \\
\text { Secondary Outcome Measures: } \\
\text { Stereoacuity [Time Frame: } 16 \text { weeks] [Designated as safety issue: No] Stereoacuity will be tested at near in } \\
\text { current refractive correction using the Randot Butterfly and Randot Preschool stereoacuity tests }\end{array}$
\end{tabular}




\section{NCT02200211 (Continued)}

Ocular Alignment [Time Frame: 16 weeks] [Designated as safety issue: No] Ocular alignment will be assessed in current refractive correction by the cover/uncover test, simultaneous prism and cover test (SPCT), and prism and alternate cover test (PACT) in primary gaze at distance ( 3 meters) and at near ( $1 / 3$ meter)

Diplopia Questionnaire [Time Frame: 16 weeks] [Designated as safety issue: Yes] The child and parent(s) will be specifically questioned regarding the presence and frequency of any diplopia since the last study visit using a standardized diplopia assessment 


\section{DATA ANDANALYSES}

This review has no analyses.

\section{ADDITIONAL TABLES}

Table 1. Summary of published non-randomised, uncontrolled studies of binocular treatment for amblyopia

\begin{tabular}{|c|c|c|c|c|c|c|c|c|c|c|c|c|c|c|}
\hline & $\begin{array}{l}\text { Treat- } \\
\text { ment }\end{array}$ & $\mathbf{N}$ & $\begin{array}{l}\text { Age } \\
\text { range } \\
\text { (mean) }\end{array}$ & $\begin{array}{l}\text { Con- } \\
\text { trol } \\
\text { group }\end{array}$ & $\begin{array}{l}\text { Type } \\
\text { of } \\
\text { am- } \\
\text { bly- } \\
\text { opia }\end{array}$ & $\begin{array}{l}\text { Pre- } \\
\text { vious } \\
\text { treat- } \\
\text { ment } \\
\text { other } \\
\text { than } \\
\text { glasses }\end{array}$ & $\begin{array}{l}\text { Treat- } \\
\text { ment } \\
\text { dura- } \\
\text { tion }\end{array}$ & $\begin{array}{l}\text { Total } \\
\text { dose } \\
\text { re- } \\
\text { ceived }\end{array}$ & $\begin{array}{l}\text { Daily } \\
\text { dose } \\
\text { re- } \\
\text { ceived }\end{array}$ & $\begin{array}{l}\text { Com- } \\
\text { pli- } \\
\text { ance } \\
\%\end{array}$ & $\begin{array}{l}\text { Visual } \\
\text { acuity } \\
\text { gain } \\
\text { am- } \\
\text { bly- } \\
\text { opic } \\
\text { eye in } \\
\text { log- } \\
\text { MAR } \\
\text { (SD) }\end{array}$ & $\begin{array}{l}\text { Visual } \\
\text { acuity } \\
\% \\
\text { change } \\
\text { in } \\
\text { am- } \\
\text { bly- } \\
\text { opic } \\
\text { eye * }\end{array}$ & $\begin{array}{l}\text { Stereoar } \\
\text { ity } \\
\text { gain }\end{array}$ & $\begin{array}{l}\text { Re- } \\
\text { cur- } \\
\text { rence }\end{array}$ \\
\hline $\begin{array}{l}\text { Hess } \\
2010 a ; \\
\text { Hess } \\
2010 b\end{array}$ & $\begin{array}{l}\text { Anti- } \\
\text { sup- } \\
\text { pres- } \\
\text { sion: } \\
\text { di- } \\
\text { chop- } \\
\text { tic co- } \\
\text { herent } \\
\text { mo- } \\
\text { tion, } \\
\text { via } \\
\text { lentic- } \\
\text { ular } \\
\text { over- } \\
\text { lay/ } \\
\text { red- } \\
\text { green } \\
\text { glasses } \\
\text { or } \\
\text { head- } \\
\text { mounter } \\
\text { dis- } \\
\text { play }\end{array}$ & 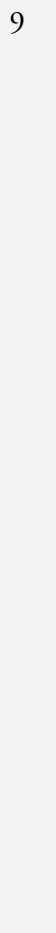 & $\begin{array}{l}24-49 \\
(39.6)\end{array}$ & No & $\begin{array}{l}\text { Stra- } \\
\text { bis- } \\
\text { mic, } \\
\text { com- } \\
\text { bined } \\
\text { mech- } \\
\text { anism }\end{array}$ & $\begin{array}{l}5 / 9 \\
\text { occlu- } \\
\text { sion }\end{array}$ & $\begin{array}{l}\text { Around } \\
60 \\
\text { trials/ } \\
\text { block } \\
(0.5 \\
\text { to } 3 . \\
7 \text { per } \\
\text { week, } \\
\text { i.e. } \\
1-3 \\
\text { hours } \\
\text { in 2- } \\
3 \text { days } \\
\text { for } \\
2-6 \\
\text { weeks })\end{array}$ & $\begin{array}{l}8.2 \\
\text { blocks } \\
\text { per } \\
\text { week } \\
\text { (SD } 6 . \\
3 \text { ) }\end{array}$ & - & - & 0.26 & $\begin{array}{l}\text { Not } \\
\text { speci- } \\
\text { fied }\end{array}$ & $\begin{array}{l}\text { "sig- } \\
\text { nifi- } \\
\text { cant" }\end{array}$ & $\begin{array}{l}\text { Not } \\
\text { speci- } \\
\text { fied }\end{array}$ \\
\hline $\begin{array}{l}\text { Hess } \\
2012\end{array}$ & $\begin{array}{l}\text { Anti- } \\
\text { sup- } \\
\text { pres- } \\
\text { sion: } \\
\text { Tetris } \\
\text { with } \\
\text { mod- } \\
\text { ula- }\end{array}$ & 10 & $\begin{array}{l}17-51 \\
(33.8)\end{array}$ & No & All & $\begin{array}{l}4 / 10 \\
\text { occlu- } \\
\text { sion }\end{array}$ & $\begin{array}{l}0.5-2 \\
\text { hours } \\
\text { per } \\
\text { day } \\
\text { for 1- } \\
9 \\
\text { weeks }\end{array}$ & $\begin{array}{l}15 \text { ses- } \\
\text { sions } \\
(\mathrm{SD} 4)\end{array}$ & $\begin{array}{l}45 \\
\text { min to } \\
1 \text { hour }\end{array}$ & - & $\begin{array}{l}0.19 \\
(0.17)\end{array}$ & $\begin{array}{l}\text { Not } \\
\text { speci- } \\
\text { fied }\end{array}$ & $\begin{array}{l}6 / 10 \\
\mathrm{im}- \\
\text { proved }\end{array}$ & $\begin{array}{l}\text { Nil at } \\
1-2 \\
\text { months } \\
\text { (in 4/ } \\
10)\end{array}$ \\
\hline
\end{tabular}




\begin{tabular}{|c|c|c|c|c|c|c|c|c|c|c|c|c|c|c|}
\hline & $\begin{array}{l}\text { tion of } \\
\text { con- } \\
\text { trast } \\
\text { on } \\
\text { iPod }\end{array}$ & & & & & & & & & & & & & \\
\hline $\begin{array}{l}\text { Knox } \\
2012\end{array}$ & $\begin{array}{l}\text { Anti- } \\
\text { sup- } \\
\text { pres- } \\
\text { sion: } \\
\text { Tetris } \\
\text { game } \\
\text { using } \\
\text { head- } \\
\text { mounter } \\
\text { dis- } \\
\text { play } \\
\text { gog- } \\
\text { gles }\end{array}$ & 14 & $\begin{array}{l}5-14 \\
(8.5)\end{array}$ & No & All & $\begin{array}{l}\text { All } \\
\text { occlu- } \\
\text { sion } \\
\text { (at } \\
\text { least } 6 \\
\text { months) }\end{array}$ & $\begin{array}{l}1 \text { hour } \\
\text { for } \\
5 \text { days } \\
\text { in } 1 \\
\text { week }\end{array}$ & $\begin{array}{l}5 \\
\text { hours }\end{array}$ & 1 hour & All & 0.09 & $22 \%$ & $\begin{array}{l}7 / 14 \\
\text { (small } \\
\text { squint) } \\
, \quad 4 / 7 \\
\text { signif- } \\
\text { icant }\end{array}$ & $\begin{array}{l}\text { Not } \\
\text { speci- } \\
\text { fied }\end{array}$ \\
\hline $\begin{array}{l}\text { To } \\
2011\end{array}$ & $\begin{array}{l}\text { Anti- } \\
\text { sup- } \\
\text { pres- } \\
\text { sion: } \\
\text { Tetris } \\
\text { game, } \\
\text { inter- } \\
\text { leaved } \\
\text { breaks, } \\
\text { via } \\
\text { lentic- } \\
\text { ular } \\
\text { layer }\end{array}$ & 9 & $\begin{array}{l}18-51 \\
(35.5)\end{array}$ & No & All & $\begin{array}{l}\text { Not } \\
\text { speci- } \\
\text { fied }\end{array}$ & $\begin{array}{l}10- \\
19 \text { ses- } \\
\text { sions }\end{array}$ & $\begin{array}{l}15.75 \\
\text { hours } \\
(0.88- \\
27.42 \\
\text { hours } \\
\text { per } \\
\text { week })\end{array}$ & $\begin{array}{l}\text { Not } \\
\text { speci- } \\
\text { fied }\end{array}$ & All & $\begin{array}{l}0.16 \\
(0.18)\end{array}$ & $\begin{array}{l}\text { Not } \\
\text { speci- } \\
\text { fied } \\
\text { (fel- } \\
\text { low- } \\
\text { eye } \\
\text { acu- } \\
\text { ity not } \\
\text { avail- } \\
\text { able) }\end{array}$ & $\begin{array}{l}\text { Trend } \\
\text { of im- } \\
\text { prove- } \\
\text { ment }\end{array}$ & $\begin{array}{l}\text { Not } \\
\text { speci- } \\
\text { fied }\end{array}$ \\
\hline $\begin{array}{l}\mathrm{Li} \\
2014\end{array}$ & 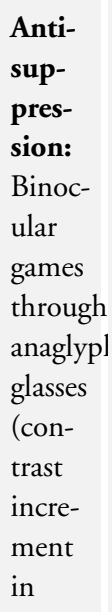 & $\begin{array}{l}45 / 50 \\
\text { binoc- } \\
\text { ular } \\
\text { group, } \\
24 / 25 \\
\text { sham } \\
\text { group }\end{array}$ & $4-12$ & $\begin{array}{l}\text { Yes } \\
\text { (sham } \\
\text { game } \\
\text { and +l } \\
- \\
\text { occlu- } \\
\text { sion) }\end{array}$ & All & $\begin{array}{l}77 \% \\
\text { occlu- } \\
\text { sion } \\
\text { or at- } \\
\text { ropine } \\
\text { for } \\
\text { around } \\
1.9 \\
\text { years } \\
(\mathrm{n}= \\
58)\end{array}$ & $\begin{array}{l}4 \\
\text { hours/ } \\
\text { week } \\
\text { for } 4 \\
\text { weeks } \\
(+\quad 4 \\
\text { weeks } \\
\text { in } \\
60 \% \\
\text { binoc- } \\
\text { ular, } \\
\text { but no } \\
\text { gain) }\end{array}$ & $\begin{array}{l}\geq \\
\text { hour } \\
\text { per } \\
\text { week, } \\
4 \\
\text { weeks } \\
\text { (i.e. } \\
25 \% \\
\text { pre- } \\
\text { scribed } \\
\text { dose) }\end{array}$ & - & $\begin{array}{l}34 / 45 \\
(76 \%)\end{array}$ & $\begin{array}{l}0.08 \\
(0.01)\end{array}$ & $\begin{array}{l}\text { Not } \\
\text { spec- } \\
\text { ified } \\
\text { (not } \\
\text { indi- } \\
\text { vidual } \\
\text { acuities, } \\
\text { also in } \\
\text { supp. } \\
\text { mate- } \\
\text { rial) }\end{array}$ & $\begin{array}{l}5 / 50, \\
\text { not } \\
\text { signif- } \\
\text { icant }\end{array}$ & $\begin{array}{l}\text { Nil } \\
\text { at } 3 \\
\text { months }\end{array}$ \\
\hline
\end{tabular}


Table 1. Summary of published non-randomised, uncontrolled studies of binocular treatment for amblyopia

\begin{tabular}{|c|c|c|c|c|c|c|c|c|c|c|c|c|c|c|}
\hline & $\begin{array}{l}\text { fellow } \\
\text { eye) }\end{array}$ & & & & & & & & & & & & & \\
\hline $\begin{array}{l}\text { Waddin } \\
\text { ham } \\
2006\end{array}$ & $\begin{array}{l}\text { I-BiT: } \\
\text { Videos } \\
\text { and } \\
\text { mod- } \\
\text { ified } \\
\text { video } \\
\text { games } \\
\text { (im- } \\
\text { bal- } \\
\text { anced } \\
\text { visual } \\
\text { scene } \\
\text { to } \\
\text { favour } \\
\text { am- } \\
\text { bly- } \\
\text { opic } \\
\text { eye) }\end{array}$ & 6 & $\begin{array}{l}5.42- \\
7.75 \\
(6.25)\end{array}$ & No & All & $\begin{array}{l}3 \text { oc- } \\
\text { clu- } \\
\text { sion, } 3 \\
\text { nei- } \\
\text { ther } \\
\text { occlu- } \\
\text { sion } \\
\text { nor at- } \\
\text { ropie }\end{array}$ & $\begin{array}{l}7 \quad \text { to } \\
15 \text { ses- } \\
\text { sions } \\
\text { of } 20 \\
\text { min- } \\
\text { utes } \\
\text { each }\end{array}$ & $\begin{array}{l}\text { mean } \\
4.4 \\
\text { hours }\end{array}$ & $\begin{array}{l}1 \text { to } 2 \\
\text { ses- } \\
\text { sions } \\
\text { of } 20 \\
\text { min- } \\
\text { utes } \\
\text { twice } \\
\text { a week }\end{array}$ & - & $\begin{array}{l}0.325 \\
\text { in } 5 \text { of } \\
6 \text { chil- } \\
\text { dren }\end{array}$ & $42 \%$ & - & $\begin{array}{l}\text { Not } \\
\text { speci- } \\
\text { fied }\end{array}$ \\
\hline $\begin{array}{l}\text { Her- } \\
\text { bison } \\
2013\end{array}$ & $\begin{array}{l}\text { I-BiT: } \\
\text { Videos } \\
\text { and } \\
\text { mod- } \\
\text { ified } \\
\text { video } \\
\text { games } \\
\text { (im- } \\
\text { bal- } \\
\text { anced } \\
\text { visual } \\
\text { scene } \\
\text { to } \\
\text { favour } \\
\text { am- } \\
\text { bly- } \\
\text { opic } \\
\text { eye) }\end{array}$ & 10 & $\begin{array}{l}4-8(5 . \\
4)\end{array}$ & No & All & $\begin{array}{l}\text { All, } \\
\text { occlu- } \\
\text { sion or } \\
\text { at- } \\
\text { ropine }\end{array}$ & $\begin{array}{l}6 \\
\text { weeks, } \\
0-10 \\
\text { games } \\
+\quad 15- \\
30 \\
\text { videos }\end{array}$ & $\begin{array}{l}159.3 \\
\min \end{array}$ & $\begin{array}{l}0-10 \\
\text { to } 15- \\
30 \\
\text { min } \\
\text { per } \\
\text { day }\end{array}$ & $\begin{array}{l}88 . \\
5 \%\end{array}$ & $\begin{array}{l}0 . \\
18(0 . \\
143)\end{array}$ & $\begin{array}{l}32 . \\
3 \%\end{array}$ & $\begin{array}{l}\text { Not } \\
\text { mea- } \\
\text { sured }\end{array}$ & $\begin{array}{l}0.055 \\
\text { at } 10 \\
\text { weeks } \\
\text { (in 6/ } \\
\text { 9) }\end{array}$ \\
\hline $\begin{array}{l}\text { Bossi } \\
2014\end{array}$ & $\begin{array}{l}\text { Bal- } \\
\text { anced } \\
\text { binoc- } \\
\text { ular } \\
\text { view- } \\
\text { ing: }\end{array}$ & 8 & $\begin{array}{l}6-11 \\
(9.46)\end{array}$ & No & $\begin{array}{l}\text { Ani- } \\
\text { sometro }\end{array}$ & None & $\begin{array}{l}\text { Around } \\
60 \\
\text { hours } \\
\text { (1 } \\
\text { hour/ }\end{array}$ & $\begin{array}{l}48 \\
\text { hours } \\
18 \\
\text { min }\end{array}$ & $\begin{array}{l}56 \\
\text { min } \\
\text { per } \\
\text { day }\end{array}$ & $90 \%$ & $\begin{array}{l}0.26 \\
(0.28)\end{array}$ & $29 \%$ & $\begin{array}{l}6 / 7 \text {, } \\
\text { signif- } \\
\text { icant } \\
\text { mean } \\
\text { gain }\end{array}$ & $\begin{array}{l}0.02 \\
\text { at } 14 \\
\text { weeks } \\
\text { (in 6/ } \\
7 \text { ) }\end{array}$ \\
\hline
\end{tabular}




\begin{tabular}{|c|c|c|}
\hline $\begin{array}{l}\text { Watch- } \\
\text { ing } \\
\text { mod- } \\
\text { ified } \\
\text { movies } \\
\text { wear- } \\
\text { ing } \\
\text { 3D } \\
\text { glasses }\end{array}$ & day) & $\begin{array}{l}\text { of } 165 \\
\text { sec- } \\
\text { onds } \\
\text { of arc }\end{array}$ \\
\hline
\end{tabular}

SD: standard deviation

* calculated as (AEs-AEe)/(AEs-Fee), where AEs and AEe are respectively visual acuity values in amblyopic eye at entry (best-corrected visual acuity) and exit, FEe is the acuity in the fellow eye at entry (baseline)

Table 2. Data extraction form

Review author

Study ID

Dates If not available, comment "dates not available“

when study was

conducted

Funding source

(s)
Declarations of interest by re- searchers

\begin{tabular}{|c|c|}
\hline Methods & $\begin{array}{l}\text { Study design (RCT) } \\
\text { Interventions; mean dose prescribed and mean dose received }\end{array}$ \\
\hline Participants & $\begin{array}{l}\text { Total number, number in each group (sample size) } \\
\text { Comparability } \\
\text { Setting }\end{array}$ \\
\hline Risk of bias & Assessed using risk of bias tool (see Handbook) \\
\hline $\begin{array}{l}\text { Outcomes (as } \\
\text { defined in study) } \\
\text { Please specify } \\
\text { which }\end{array}$ & $\begin{array}{l}\text { Primary outcome } \\
\text { Mean distance ( } 3,4 \text { or } 6 \mathrm{~m}) \text { BCVA in the amblyopic eye at } 12 \text { months after the cessation of the interventions in } \\
\text { logMAR units on an age-appropriate acuity test } \\
\text { Secondary outcomes } \\
\text { - main secondary outcome: mean distance }(3,4 \text { or } 6 \mathrm{~m}) \text { BCVA in the amblyopic eye at any timepoint during } \\
\text { or after cessation of treatment in logMAR units on an age-appropriate acuity test } \\
\text { - proportion of change in BCVA defined as "(BCVA of amblyopic eye at start - BCVA of amblyopic eye at }\end{array}$ \\
\hline
\end{tabular}


Table 2. Data extraction form (Continued)

end of treatment)/(BCVA of amblyopic eye at start - BCVA of fellow eye at end of treatment)" (Stewart 2003)

- stereopsis 12 months after cessation of treatment in seconds of arc

- stereopsis at any timepoint during or after cessation of treatment in seconds of arc

- proportion of participants achieving normal stereoacuity score of 60 seconds of arc or better 12 months after cessation of treatment

- proportion of participants achieving normal stereoacuity score of 60 seconds of arc or better at any timepoint during or after cessation of treatment

- proportion of participants with improvement in stereoacuity of $2 \log$ levels or more (with 2 levels being the test-retest variability for stereoacuity tests) at 12 months after cessation of treatment (Adams 2009; Wallace 2011)

- proportion of participants with improvement in stereoacuity of $2 \log$ levels or more at any timepoint during or after cessation of treatment

- mean change in stereoacuity in log seconds of arc defined as "stereoacuity at start - stereoacuity at end of treatment"

- compliance or adherence to interventions as daily dose in hours/day, determined by occlusion dose monitors, electronic compliance measures of binocular treatments, or parental treatment diaries (ratio of received dose/prescribed daily dose)

- compliance or adherence to interventions as total dose, determined by occlusion dose monitors, electronic compliance measures of binocular treatments, or parental treatment diaries (ratio of received dose/prescribed total dose)

- impact of treatment on quality of life measured by a validated tool such as CAT-QoL (Carlton 2013) or ATI (Felius 2010)

- proportion of participants experiencing adverse events such as diplopia (double vision) or loss of BCVA > 1 line in either eye

- proportion of participants experiencing regression of BCVA in the amblyopic eye to baseline level (Malik 1975) or recurrence defined as a 2 or more logMAR lines (0.2 logMAR)

- deterioration in amblyopic eye BCVA (Holmes 2004) 12 months after cessation of treatment

- where available, we will include analysis of cost-effectiveness or cost-utility of treatments

Interventions Intervention 1 = Standard care (occlusion or pharmacological blurring)

\section{PRIMARY \\ OUTCOME: \\ Mean distance \\ (3, 4 or $6 \mathrm{~m})$ \\ BCVA in the \\ amblyopic eye \\ at 12 months af- \\ ter the cessation \\ of the \\ interventions in \\ logMAR units \\ on an age-ap- \\ propriate acuity \\ test.}

Intervention 1

Intervention 2

\begin{tabular}{l|l|l|l|l} 
Timepoint & $\begin{array}{l}\text { Total number of } \\
\text { participants }\end{array}$ & Mean & $\begin{array}{l}\text { Standard devia- } \\
\text { tion* }\end{array}$ & $\begin{array}{l}\text { Total number of } \\
\text { participants }\end{array}$
\end{tabular} Mean Standard deviation*

Binocular versus standard occlusion or blurring treatment for unilateral amblyopia in children aged three to eight years (Review) 
Table 2. Data extraction form (Continued)

Baseline (note method used to measure BCVA)

12 months after cessation of intervention

Or: improvement of BCVA from baseline

\begin{tabular}{|c|c|c|c|c|c|c|}
\hline $\begin{array}{l}\text { SECONDARY } \\
\text { OUTCOMES: } \\
\text { mean } \\
\text { distance ( } 3,4 \text { or } \\
6 \text { m) BCVA in } \\
\text { the amblyopic } \\
\text { eye at any time- } \\
\text { point during or } \\
\text { after cessation } \\
\text { of treatment in } \\
\text { logMAR units } \\
\text { on an age-ap- } \\
\text { propriate acuity } \\
\text { test }\end{array}$ & \multicolumn{3}{|l|}{ Intervention 1} & \multicolumn{3}{|l|}{ Intervention 2} \\
\hline Timepoint & $\begin{array}{l}\text { Total number of } \\
\text { participants }\end{array}$ & Mean & $\begin{array}{l}\text { Standard devia- } \\
\text { tion* }\end{array}$ & $\begin{array}{l}\text { Total number of } \\
\text { participants }\end{array}$ & Mean & Standard deviation* \\
\hline \multicolumn{7}{|l|}{$\begin{array}{l}\text { Baseline (note } \\
\text { method used to } \\
\text { measure BCVA) }\end{array}$} \\
\hline \multicolumn{7}{|l|}{$\begin{array}{l}\text { Second } \\
\text { timepoint } \\
\text { (please specify) }\end{array}$} \\
\hline $\begin{array}{l}\text { Or: improve- } \\
\text { ment of BCVA } \\
\text { from baseline }\end{array}$ & & & & & & \\
\hline
\end{tabular}

\begin{tabular}{l|l|l|}
$\begin{array}{l}\text { SECONDARY Intervention } 1 \\
\text { OUTCOMES: }\end{array}$ & Intervention 2 \\
\hline $\begin{array}{l}\text { propor- } \\
\text { tion of change }\end{array}$ & \\
\hline in BCVA de- \\
fined \\
by the equation
\end{tabular}

Binocular versus standard occlusion or blurring treatment for unilateral amblyopia in children aged three to eight years (Review) 
Table 2. Data extraction form (Continued)

\section{“(BCVA of am- blyopic eye at start - BCVA of ambly- \\ opic eye at end of treatment) /(BCVA of am- blyopic eye at start - BCVA of fellow eye at end of treatment)"}

\begin{tabular}{|c|c|c|c|c|c|c|}
\hline Timepoint & $\begin{array}{l}\text { Total number of } \\
\text { participants }\end{array}$ & Mean & $\begin{array}{l}\text { Standard devia- } \\
\text { tion* }\end{array}$ & $\begin{array}{l}\text { Total number of } \\
\text { participants }\end{array}$ & Mean & Standard deviation* \\
\hline \multicolumn{7}{|l|}{ End of treatment } \\
\hline $\begin{array}{l}\text { SECONDARY } \\
\text { OUTCOMES: } \\
\text { Stereoacuity } 12 \\
\text { months af- } \\
\text { ter cessation of } \\
\text { intervention in } \\
\text { seconds of arc }\end{array}$ & \multicolumn{3}{|l|}{ Intervention 1} & \multicolumn{3}{|l|}{ Intervention 2} \\
\hline Timepoint & $\begin{array}{l}\text { Total number of } \\
\text { participants }\end{array}$ & Mean & $\begin{array}{l}\text { Standard devia- } \\
\text { tion* }\end{array}$ & $\begin{array}{l}\text { Total number of } \\
\text { participants }\end{array}$ & Mean & Standard deviation* \\
\hline $\begin{array}{l}\text { Baseline (note } \\
\text { method } \\
\text { used to measure } \\
\text { stereoacuity) }\end{array}$ & & & & & & \\
\hline
\end{tabular}

12 months after cessation of intervention

\begin{tabular}{|c|c|c|c|c|c|c|}
\hline $\begin{array}{l}\text { SECONDARY } \\
\text { OUTCOMES: } \\
\text { Stereoacuity at } \\
\text { any timepoint } \\
\text { during or after } \\
\text { cessation of in- } \\
\text { tervention }\end{array}$ & \multicolumn{3}{|l|}{ Intervention 2} & \multicolumn{3}{|l|}{ Intervention 2} \\
\hline Timepoint & $\begin{array}{l}\text { Total number of } \\
\text { participants }\end{array}$ & Mean & $\begin{array}{l}\text { Standard devia- } \\
\text { tion* }\end{array}$ & $\begin{array}{l}\text { Total number of } \\
\text { participants }\end{array}$ & Mean & Standard deviation* \\
\hline
\end{tabular}

Baseline

Binocular versus standard occlusion or blurring treatment for unilateral amblyopia in children aged three to eight years (Review) 
Table 2. Data extraction form (Continued)

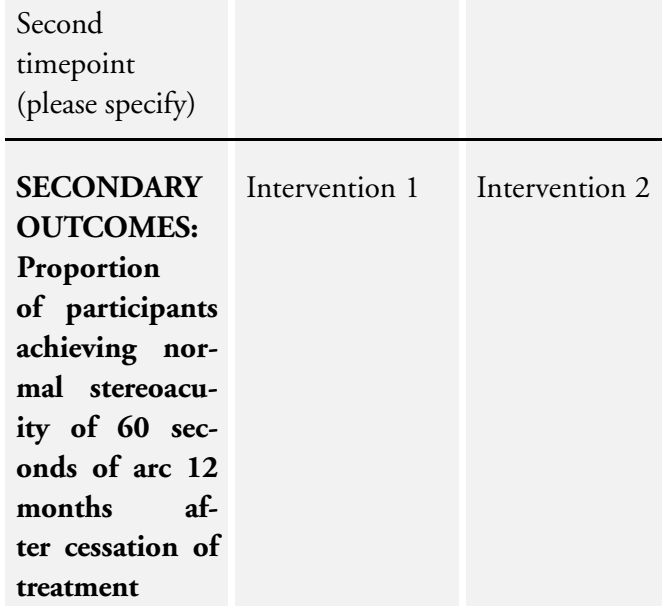

\begin{tabular}{l|l|l|l|l}
\hline Timepoint & $\begin{array}{l}\text { Total number of } \\
\text { participants }\end{array}$ & Mean & $\begin{array}{l}\text { Standard devia- } \\
\text { tion* }\end{array}$ & $\begin{array}{l}\text { Total number of } \\
\text { participants }\end{array}$ \\
\hline
\end{tabular}

12 months af-

ter cessation of treatment (note method

used to measure

stereoacuity)

\section{SECONDARY OUTCOMES: \\ Propor- \\ tion of partici- \\ pants achieving \\ normal \\ stereoacuity of \\ 60 seconds of arc at any tim- point during or after cessation \\ of treatment}

\begin{tabular}{l|l|l|l|l}
\hline Timepoint & $\begin{array}{l}\text { Total number of } \\
\text { participants }\end{array}$ & Mean & $\begin{array}{l}\text { Standard devia- } \\
\text { tion* }\end{array}$ & $\begin{array}{l}\text { Total number of } \\
\text { participants }\end{array}$ \\
\hline
\end{tabular}

\section{Second}

timepoint

(please specify)

Intervention $1 \quad$ Intervention 2

i-


Table 2. Data extraction form (Continued)

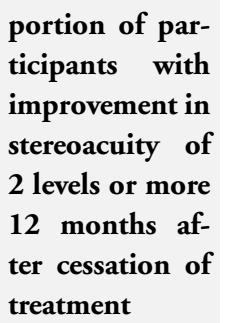

\begin{tabular}{l|l|l|l|l}
\hline Timepoint & $\begin{array}{l}\text { Total number of } \\
\text { participants }\end{array}$ & Mean & $\begin{array}{l}\text { Standard devia- } \\
\text { tion* }\end{array}$ & $\begin{array}{l}\text { Total number of } \\
\text { participants }\end{array}$ \\
\hline
\end{tabular}

12 months after cessation of treatment (note method used to measure stereoacuity)

\begin{tabular}{|c|c|c|c|c|c|c|}
\hline $\begin{array}{l}\text { SECONDARY } \\
\text { OUTCOMES: } \\
\text { Pro- } \\
\text { portion of par- } \\
\text { ticipants with } \\
\text { improvement in } \\
\text { stereoacu- } \\
\text { ity of } 2 \text { levels } \\
\text { or more at any } \\
\text { timepoint dur- } \\
\text { ing or after ces- } \\
\text { sation of treat- } \\
\text { ment }\end{array}$ & Intervention 1 & Intervention 2 & & & & \\
\hline Timepoint & $\begin{array}{l}\text { Total number of } \\
\text { participants }\end{array}$ & Mean & $\begin{array}{l}\text { Standard devia- } \\
\text { tion* }\end{array}$ & $\begin{array}{l}\text { Total number of } \\
\text { participants }\end{array}$ & Mean & Standard deviation* \\
\hline
\end{tabular}

Second

timepoint

(please specify)

\section{SECONDARY}

\section{OUTCOMES:}

Mean change in

stereoacuity in

loga-

rcsec defined as

"stereoacuity at

start

- stereoacuity at 
Table 2. Data extraction form (Continued)

\begin{tabular}{l|l|l|l|l}
$\begin{array}{l}\text { end } \\
\text { treatment“ }\end{array}$ & of & & \\
\hline Timepoint & $\begin{array}{l}\text { Total number of } \\
\text { participants }\end{array}$ & Mean & $\begin{array}{l}\text { Standard devia- } \\
\text { tion* }\end{array}$ & $\begin{array}{l}\text { Total number of } \\
\text { participants }\end{array}$ \\
\hline
\end{tabular}

End of treatment

(note method

used to measure

stereoacuity and

time from start

of treatment)

\section{SECONDARY \\ OUTCOMES: \\ Compliance or \\ adherence \\ to interventions \\ as daily dose in \\ hours/day (ra- \\ tio of received/ \\ prescribed)}

Intervention 1 Intervention 2

\begin{tabular}{|c|c|c|c|c|c|c|}
\hline Timepoint & $\begin{array}{l}\text { Total number of } \\
\text { participants }\end{array}$ & Mean & $\begin{array}{l}\text { Standard devia- } \\
\text { tion* }\end{array}$ & $\begin{array}{l}\text { Total number of } \\
\text { participants }\end{array}$ & Mean & Standard deviation* \\
\hline
\end{tabular}

End of interven-

tion (specify

time from start

of treatment)

\section{SECONDARY \\ OUTCOMES: \\ Compliance \\ or adherence to \\ interventions as \\ total dose (ratio \\ of received/pre- \\ scribed)}

Intervention 1 Intervention 2

\begin{tabular}{l|l|l|l|l}
\hline Timepoint & $\begin{array}{l}\text { Total number of } \\
\text { participants }\end{array}$ & Mean & $\begin{array}{l}\text { Standard devia- } \\
\text { tion* }\end{array}$ & $\begin{array}{l}\text { Total number of } \\
\text { participants }\end{array}$ \\
\hline
\end{tabular}

End of interven-

tion (specify

time from start

of treatment) 
Table 2. Data extraction form (Continued)

\begin{tabular}{|c|c|c|c|c|c|c|}
\hline $\begin{array}{l}\text { SECONDARY } \\
\text { OUTCOMES: } \\
\text { Impact on QoL }\end{array}$ & \multicolumn{3}{|l|}{ Intervention 1} & \multicolumn{3}{|l|}{ Intervention 2} \\
\hline Timepoint & $\begin{array}{l}\text { Total number of } \\
\text { participants }\end{array}$ & Mean & $\begin{array}{l}\text { Standard devia- } \\
\text { tion* }\end{array}$ & $\begin{array}{l}\text { Total number of } \\
\text { participants }\end{array}$ & Mean & Standard deviation* \\
\hline \multicolumn{7}{|l|}{$\begin{array}{l}\text { Last mea- } \\
\text { surement in trial } \\
\text { (specify } \\
\text { time from start } \\
\text { of treatment) }\end{array}$} \\
\hline $\begin{array}{l}\text { SECONDARY } \\
\text { OUTCOMES: } \\
\text { Adverse events } \\
\text { (diplopia, loss of } \\
\text { BCVA in ambly- } \\
\text { opic eye > } 0 \text {. } \\
10 \text { logMAR, loss } \\
\text { of BCVA in fel- } \\
\text { low eye > } 0.10 \\
\text { logMAR, regres- } \\
\text { sion, recurrence, } \\
\text { other) }\end{array}$ & \multicolumn{3}{|l|}{ Intervention 1} & \multicolumn{3}{|l|}{ Intervention 2} \\
\hline Timepoint & $\begin{array}{l}\text { Total number of } \\
\text { participants }\end{array}$ & Numb & ted participants & $\begin{array}{l}\text { Total number of } \\
\text { participants }\end{array}$ & Numb & $r$ of affected participants \\
\hline \multicolumn{7}{|l|}{$\begin{array}{l}\text { Diplopia } \\
\text { at } 12 \text { months af- } \\
\text { ter start of inter- } \\
\text { vention }\end{array}$} \\
\hline $\begin{array}{l}\text { Loss of BCVA in } \\
\text { amblyopic eye > } \\
0.10 \text { logMAR at } \\
12 \text { months after } \\
\text { start of interven- } \\
\text { tion }\end{array}$ & & & & & & \\
\hline
\end{tabular}

Loss of BCVA in

fellow eye $>0$.

$10 \log$ MAR at

12 months after start of interven-

tion 
Table 2. Data extraction form (Continued)

\section{Regres- \\ sion of BCVA in \\ amblyopic eye to \\ baseline level at \\ 12 months after start of interven- \\ tion}

Recurrence: deterioration of BCVA in amblyopic eye of 0.20 $\log$ MAR or more at 12 months after start of intervention

Other (specify)

SECONDARY

Intervention 1

Intervention 2

Cost-effective-

ness or cost-util-

ity

ATI: Amblyopia Treatment Index

BCVA: best-corrected visual acuity

CAT-QoL: Child Amblyopia Treatment Questionnaire

QoL: quality of life

RCT: randomised controlled trial 


\section{A P P E N D I C E S}

\section{Appendix I. CENTRAL search strategy}

\#1 [mh amblyopia]

\#2 amblyop*

\#3 lazy near/3 eye*

\#4 [mh strabismus]

\#5 strabism* or squint*

\#6 astigmati* or meridonal

\#7 [mh anisometropia]

\#8 [mh "refractive errors"]

\#9 anisometropi*

\#10 ammetropi*

$\# 11 \# 1$ or $\# 2$ or $\# 3$ or $\# 4$ or $\# 5$ or $\# 6$ or $\# 7$ or $\# 8$ or $\# 9$ or $\# 10$

$\# 12$ [mh "computer systems"]

\#13 [mh software]

\#14 [mh "computer simulation"]

\#15 [mh "computer graphics"]

\#16 [mh "imaging, three-dimensional"]

\#17 [mh "photic stimulation"]

\#18 [mh "therapy, computer-assisted"]

\#19 [mh "play and playthings"]

\#20 [mh "video games"]

\#21 (computer) near/2 (game* or device* or application*)

\#22 handheld near/2 device*

\#23 (mobile) near/2 (phone* or app* or device*)

\#24 (perceptual) near/2 (learn* or train*)

\#25 anti-suppression therap*

\#26 mirror haploscope*

\#27 head-mounted video*

\#28 lenticular near/3 prism

\#29 Balanced Binocular Viewing

\#30 BBV

\#31 Interactive Binocular Treatment

\#32 i-bit or I-BiTTM

\#33 shutter near/3 (glasses or spectacles)

$\# 34$ virtual reality

$\# 35 \# 12$ or \#13 or \#14 or \#15 or \#16 or \#17 or \#18 or \#19 or \#20 or \#21 or \#22 or \#23 or \#24 or \#25 or \#26 or \#27 or \#28 or \#29 or \#30 or \#31 or \#32 or \#33 or \#34

\#36 \#11 and \#35

\section{Appendix 2. MEDLINE (OvidSP) search strategy}

1. randomized controlled trial.pt.

2. (randomized or randomised).ab,ti.

3. placebo.ab,ti.

4. dt.fs.

5. randomly.ab,ti.

6. trial.ab,ti.

7. groups.ab,ti.

8. or/ $1-7$

9. exp animals/

Binocular versus standard occlusion or blurring treatment for unilateral amblyopia in children aged three to eight years (Review) 
10. exp humans/

11. 9 not (9 and 10)

12. 8 not 11

13. exp amblyopia/

14. amblyop\$.tw.

15. (lazy adj3 eye $\$$ ).tw.

16. exp strabismus/

17. (strabism $\$$ or squint $\$$ ).tw.

18. (astigmati\$ or meridonal).tw.

19. anisometropia/

20. exp refractive errors/

21. anisometropi\$.tw.

22. ammetropi\$.tw.

23. or/13-22

24. exp computer systems/

25. exp software/

26. exp computer simulation/

27. computer graphics/

28. imaging, three-dimensional/

29. photic stimulation/

30. therapy, computer-assisted/

31. "play and playthings"/

32. video games/

33. (computer adj2 (game\$ or device $\$$ or application $\$$ )).tw.

34. (handheld adj2 device\$).tw.

35. (mobile adj2 (phone\$ or app\$ or device\$)).tw.

36. (perceptual adj2 (learn\$ or train\$)).tw.

37. anti-suppression therap\$.tw.

38. mirror haploscope $\$ . t w$.

39. head-mounted video $\$$.tw.

40. (lenticular adj3 prism\$).tw.

41. Balanced Binocular Viewing.tw.

42. BBV.tw.

43. Interactive Binocular Treatment.tw.

44. (i-bit or I-BiTTM).tw.

45. (shutter adj3 (glasses or spectacles)).tw.

46. virtual reality.tw.

47. or/24-46

48. 23 and 47

49. 12 and 48

The search filter for trials at the beginning of the MEDLINE strategy is from the published paper by Glanville et al (Glanville 2006).

Binocular versus standard occlusion or blurring treatment for unilateral amblyopia in children aged three to eight years (Review) 


\section{Appendix 3. EMBASE (OvidSP) search strategy}

1. exp randomized controlled trial/

2. exp randomization/

3. exp double blind procedure/

4. exp single blind procedure/

5. random\$.tw.

6. or/1-5

7. (animal or animal experiment).sh.

8. human.sh.

9.7 and 8

10. 7 not 9

11. 6 not 10

12. exp clinical trial/

13. (clin\$ adj3 trial\$).tw.

14. ((singl\$ or doubl\$ or trebl\$ or tripl\$) adj3 (blind\$ or mask\$)).tw.

15. exp placebo/

16. placebo $\$ . t w$.

17. random $\$$.tw.

18. exp experimental design/

19. exp crossover procedure/

20. exp control group/

21. exp latin square design/

22. or/ $12-21$

23. 22 not 10

24. 23 not 11

25. exp comparative study/

26. exp evaluation/

27. exp prospective study/

28. (control\$ or prospectiv $\$$ or volunteer $\$$ ).tw.

29. or $/ 25-28$

30. 29 not 10

31.30 not (11 or 23$)$

32. 11 or 24 or 31

33. exp amblyopia/

34. amblyop\$.tw.

35. (lazy adj3 eye $\$$ ).tw.

36. exp strabismus/

37. (strabism $\$$ or squint $\$$ ).tw.

38. (astigmati\$ or meridonal).tw.

39. anisometropia/

40. exp refractive errors/

41. anisometropi\$.tw.

42. ammetropi\$.tw.

43. or/33-42

44. computer/

45. computer system/

46. computer simulation/

47. computer graphics/

48. photostimulation/

49. computer assisted therapy/

50. virtual reality/

51. recreation/

Binocular versus standard occlusion or blurring treatment for unilateral amblyopia in children aged three to eight years (Review)

Copyright @ 2015 The Cochrane Collaboration. Published by John Wiley \& Sons, Ltd. 
52. play/

53. psychomotor performance/

54. (computer adj2 (game $\$$ or device $\$$ or application $\$)$ ).tw.

55. (handheld adj2 device\$).tw.

56. (mobile adj2 (phone $\$$ or app\$ or device\$)).tw.

57. (perceptual adj2 (learn\$ or train\$)).tw.

58. anti-suppression therap\$.tw.

59. mirror haploscope $\$$. tw.

60. head-mounted video $\$$.tw.

61. (lenticular adj3 prism\$).tw.

62. Balanced Binocular Viewing.tw.

63. BBV.tw.

64. Interactive Binocular Treatment.tw.

65. (i-bit or I-BiTTM).tw.

66. (shutter adj3 (glasses or spectacles)).tw.

67. virtual reality.tw.

68. or/44-67

69.43 and 68

70.32 and 69

\section{Appendix 4. metaRegister of Controlled Trials search strategy}

amblyopia AND (computer OR video OR Interactive Binocular Treatment OR i-bit OR I-BiTTM OR shutter)

\section{Appendix 5. ClinicalTrials.gov search strategy}

amblyopia AND (computer OR video OR Interactive Binocular Treatment OR i-bit OR I-BiTTM OR shutter)

\section{Appendix 6. ICTRP search strategy}

amblyopia = Condition AND computer OR video OR Interactive Binocular Treatment OR i-bit OR I-BiTTM OR shutter $=$ Intervention

\section{CONTRIBUTIONSOFAUTHORS}

VT, MB, JG, and ADN developed the background, objectives, and methods with CB's support in writing the methods section. VT and $\mathrm{ADN}$ reviewed the results of the search. $\mathrm{MB}$ and $\mathrm{ADN}$ drafted the results and discussion, and all review authors contributed critically to the final version.

\section{DECLARATIONSOF INTEREST}

No financial interests to declare. 


\section{SOURCES OF SUPPORT}

\section{Internal sources}

- National Institute for Health Research (NIHR) Biomedical Research Centre, UK.

The research was supported by the National Institute for Health Research (NIHR) Biomedical Research Centre based at Moorfields Eye Hospital NHS Foundation Trust and UCL Institute of Ophthalmology. The views expressed are those of the review author(s) and not necessarily those of the NHS, the NIHR, or the Department of Health.

\section{External sources}

- National Institute for Health Research (NIHR), UK.

- Richard Wormald, Co-ordinating Editor for the Cochrane Eyes and Vision Group (CEVG) acknowledges financial support for his CEVG research sessions from the Department of Health through the award made by the National Institute for Health Research to Moorfields Eye Hospital NHS Foundation Trust and UCL Institute of Ophthalmology for a Specialist Biomedical Research Centre for Ophthalmology.

- The NIHR also funds the CEVG Editorial Base in London.

The views expressed in this publication are those of the authors and not necessarily those of the NIHR, NHS, or the Department of Health.

\section{DIFFERENCES BETWEEN PROTOCOLANDREVIEW}

At the review stage, we decided to include methods for preparing a Summary of findings table including the use of the GRADE classification to grade the overall quality of the evidence for each specified outcome in the Data synthesis section. 